\title{
Seafood waste: a source for preparation of commercially employable chitin/chitosan materials
}

\author{
Monika Yadav ${ }^{1}$, Priynshi Goswami ${ }^{3}$, Kunwar Paritosh' ${ }^{1}$, Manish Kumar², Nidhi Pareek² \\ and Vivekanand Vivekanand ${ }^{1 *}$
}

\begin{abstract}
Modern seafood processing practices result in amassment of a large volume of waste products, i.e., skin, head, tails, shells, scales, backbones, etc. These waste products may often encompass several high-value products which are still untapped due to the dearth of appropriate management. Moreover, inadequate disposal of waste also has negative implications on both environment and human health. This seafood waste often contains a huge amount of chitin, a polysaccharide that exhibits exceptional inherent characteristics including biocompatibility, biodegradability, antimicrobial, antitumor and antioxidant activities. The present review summarizes the existing methods for recovery of chitin and its derivatives from marine waste. The preparation of chitin nanoparticles was discussed along with blending of chitin and chitosan with other biopolymers. The recent trends of the application of chitin and chitosan nanostructures in various sectors were explored. This review is an attempt to highlight the extraction methods of chitin and chitosan from marine waste resources and its transformation into valuable commercial products as a solution to waste management.
\end{abstract}

Keywords: Chitin, Chitosan, N-Acetyl glucosamine, Biopolymers, Composites, Scaffolds

\section{Introduction}

With growing population, waste generation is also increasing and major proportion of by-products generated by contemporary food remains underutilized which may often contain high-value substances. Crucial problem faced by industries and society during food processing is disposal of food waste. Around $10^{12}-10^{14}$ tons of chitin are produced annually by living organisms in ocean (Dhillon et al. 2013), out of which $2.8 \times 10^{10} \mathrm{~kg}$ is generated by arthropods in freshwater and $1.3 \times 10^{12} \mathrm{~kg}$ in marine environment (Cauchie 2002). This huge quantity of chitin would provide enough raw material, if commercial procedures were developed for extraction of commercially competent polymers. Habitually, seafood waste is burned, land filled, dumped at sea or left to get

\footnotetext{
*Correspondence: vivekanand.cee@mnit.ac.in

${ }^{1}$ Centre for Energy and Environment, Malaviya National Institute of Technology, Jaipur, Rajasthan 302017, India

Full list of author information is available at the end of the article
}

spoiled (Xu et al. 2013). If not processed properly, it may have a negative impact on human health, biodiversity and environment.

Following cellulose, chitin is the second most abundant polysaccharide. Chitin is converted into its deacetylated form, i.e., chitosan on a commercial scale. Chitin and chitosan both have enormous economic value because of their flexible biological properties. Crystallinity and insolubility of chitin demote its commercial applications. Conversion of chitin into derivatives viz. chitosan, chitooligosaccharides and glucosamine augments its biological properties and applications in agriculture, food, textile, medical and cosmetic industries.

Therefore, the focus of the present review is to provide the latest information on the preparation of chitin nanostructures from native resources through chemical and biotechnological processes. The review also highlights the chitin-based nanotechnology applications along with current patents and international projects based on chitin and chitosan. 


\section{Chitin resources in nature}

Chitin is the most abundant polysaccharide in the marine ecosystem and second in nature after cellulose. Various sources of chitin in nature have been summarized in Fig. 1. Chitin, in nature, is present in three different types of crystalline forms $\alpha, \beta$ and $\gamma$ and varies in degree of deacetylation (Aam et al. 2010). The primary sources of chitin are the crustacean shells obtained from the shellfish processing businesses. These crustaceans include crabs, shrimps, lobsters and krill. The hierarchical arrangement of chitin fibrils in crab shells has been explained in Fig. 2.

$\alpha$ Chitin is found in yeast and fungal cell wall, shrimp shells, insect cuticles as well as in crab and lobster tendons and shells (Kaur and Dhillon 2014; Merzendorfer and Zimoch 2003; João et al. 2015). In $\alpha$ chitin, polysaccharide chains are arranged in antiparallel orientation which allows maximum bonds. Therefore, $\alpha$ chitin is the most stable form of chitin in nature resulting in chitin fibrils with high crystallinity index (80\%). The $\beta$ chitin is generally found in squid pens and in the tubes synthesized by vestimentiferan worm and pogonophoran. It also occurs in aphrodite chaetae and in lorica produced by some protozoa or seaweeds. In monocrystalline spine, a more pure form of $\beta$ chitin has been found to be excreted by Thalassiosira fluviatilis,

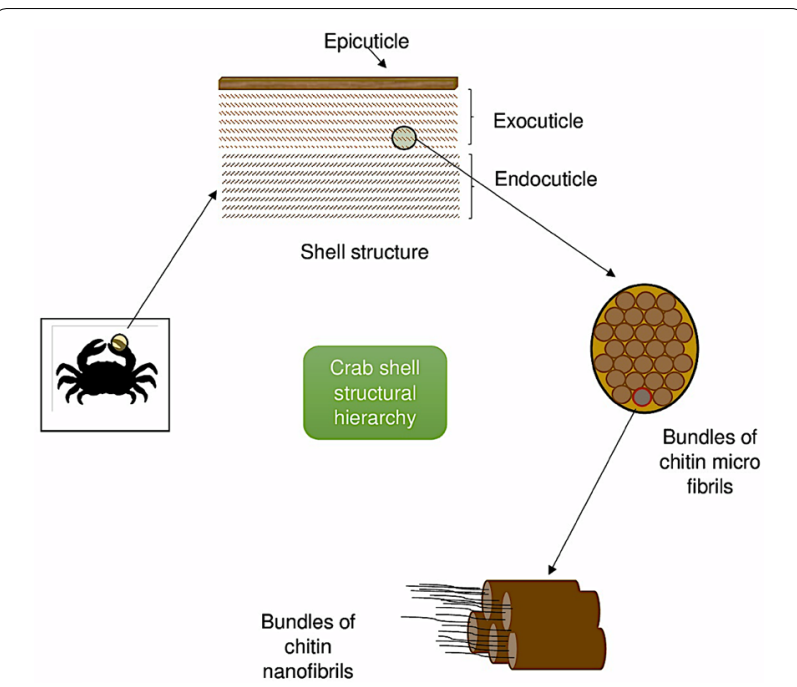

Fig. 2 Hierarchical arrangements of chitin fibers in crab shell

a diatom. In $\beta$ chitin, polymer chains are arranged in parallel orientation and the crystallinity index of chitin fibrils is around 70\%. Higher distance between adjacent polymer chains makes this form more reactive and readily soluble in solvents (João et al. 2015). $\gamma$ Chitin

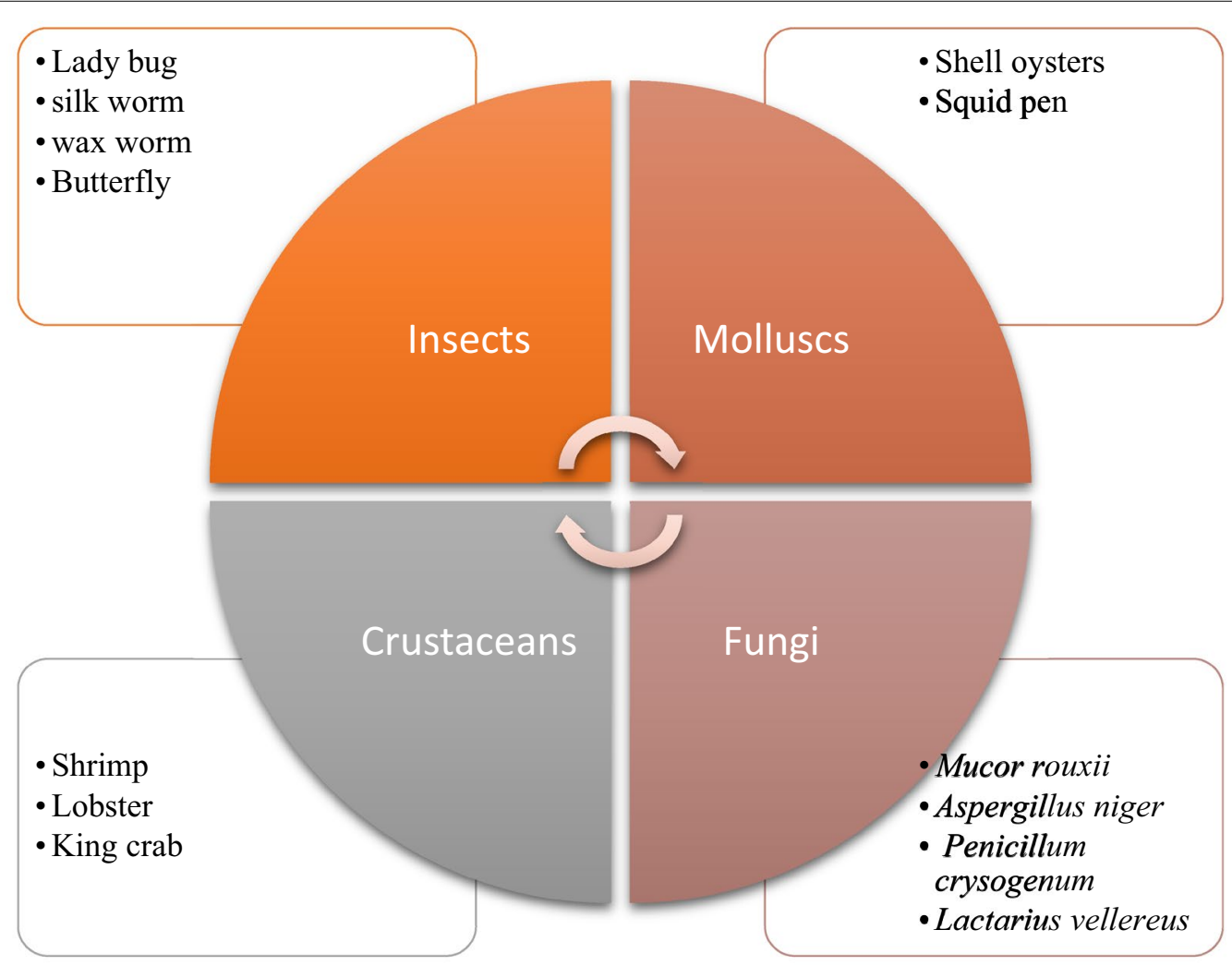

Fig. 1 Sources of chitin 
comprised of combination of $\alpha$ - and $\beta$ chitin-type orientation in which two parallel polymer chains are arranged alternatively with one anti parallel chain.

Chitosan is a linear polysaccharide comprising of deacetylated and acetylated units of D-glucosamine linked by $\beta(1,4)$ glycosidic bonds. Such polymer is obtained by deacetylation of chitin, where acetate ions and an $-\mathrm{NH}_{2}$ group are produced through hydrolysis of acetamide group. Ratio of glucosamine and $\mathrm{N}$-acetyl glucosamine generally defines the degree of deacetylation in chitosan. The higher $N$-acetyl glucosamine percent than glucosamine is found in chitin, while glucosamine percent is higher than $\mathrm{N}$-acetyl glucosamine in chitosan (Viarsagh et al. 2010; Ramírez et al. 2010). The degree of deacetylation influences both chemical (tensile strength, solubility, surface area, viscosity, conductivity, porosity and flexibility) and biological properties (adsorption enhancer, biodegradability, antioxidant, bioavailability and biocompatibility) depending on process conditions (Benhabiles et al. 2012; Park and Kim 2010). Chemical structure of chitin and chitosan is shown in Fig. 3.

\section{Isolation of chitin from natural resources}

Due to low biodegradation rate, seafood processing industries assemble a large quantity of scrap (Abdou et al. 2008). When dumped into the sea, these lumps of food scraps caused pollution in coastal areas. This marine waste can be exploited as a substrate for chitosan and chitin production. For obtaining chitin, its extraction from natural sources is the most crucial step. The parameters and conditions of extraction regulate numerous characteristics of purified chitin such as molecular weight, degree of deacetylation, purity and polydispersity index. All these characteristics majorly influence the application of chitin in countless realms. Even though chemical extraction is eco-unfriendly and uneconomical process which adversely affects the physical and chemical properties of chitin, and removes minerals and proteins, still, it is the most commonly applied method on commercial scale. However, due to these disadvantages, biological extraction has been recently attracting interest, since it is cheaper and safer treatment for chitin retrieval but limited to laboratory scale only (Dhillon et al. 2013). The process of chitin extraction from natural resources and its conversion into chitosan has been outlined in Fig. 4.

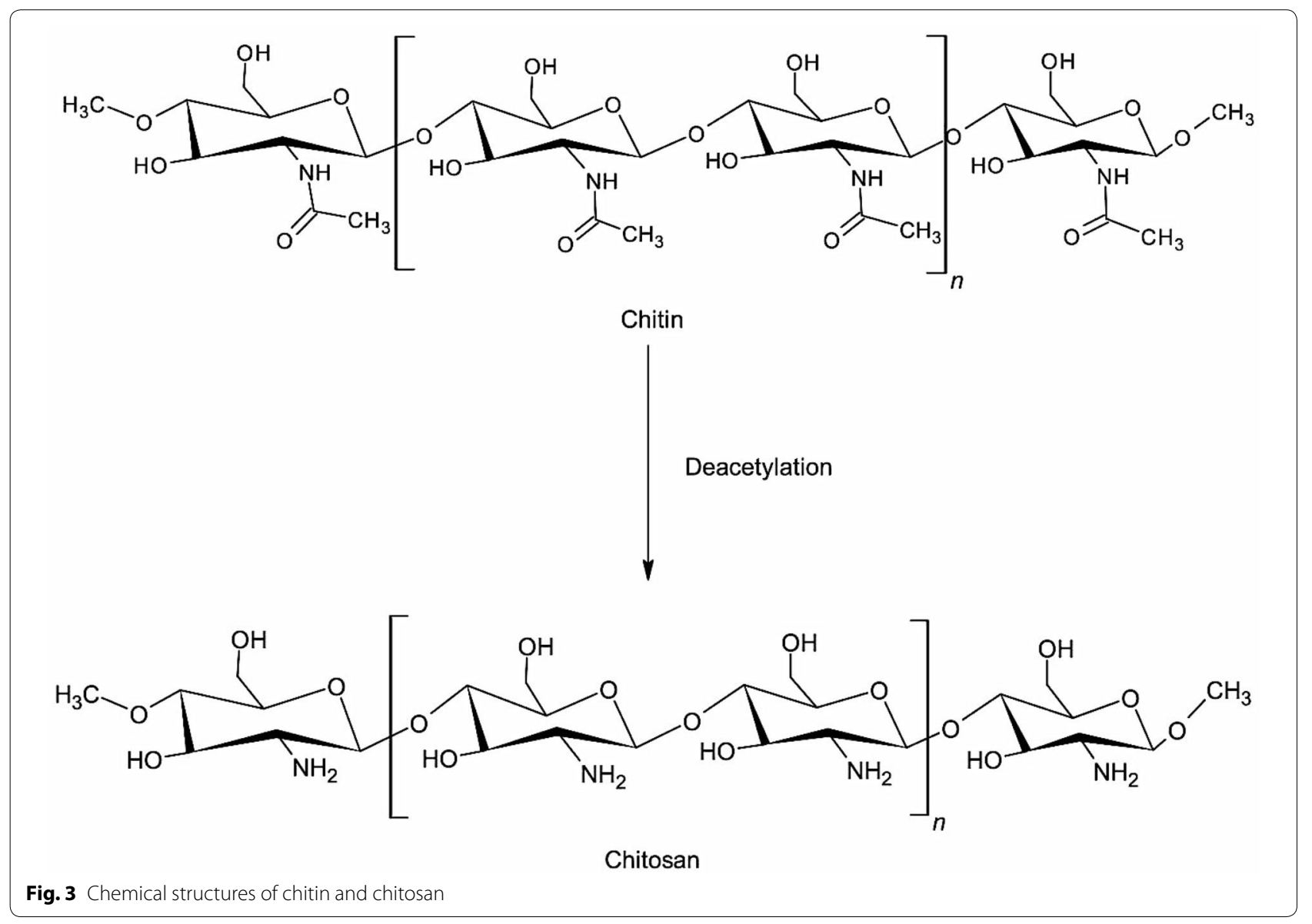




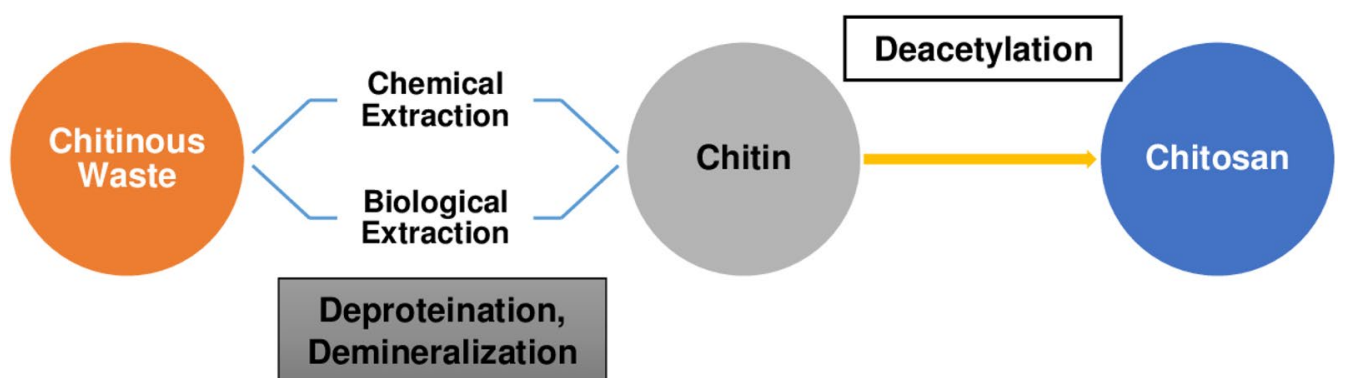

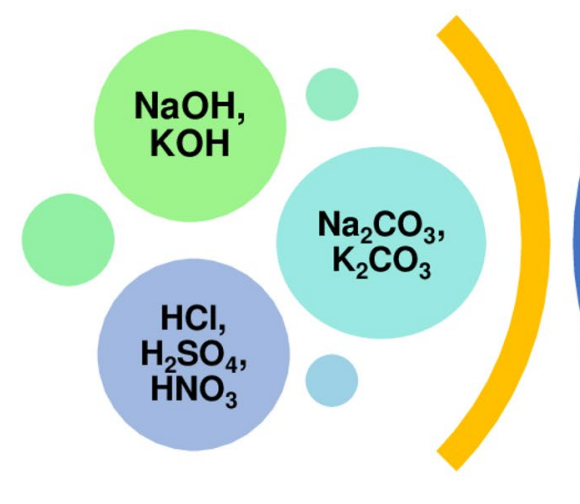

Chemical Extraction

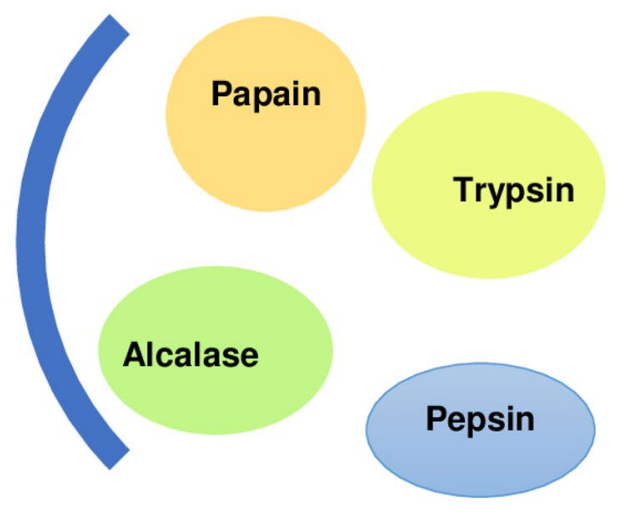

Biological Extraction

Fig. 4 Chitin and chitosan extraction from chitinous marine waste

\section{Chemical extraction}

Shells obtained from diverse sources are subjected to washing and drying followed by crushing into powder (Islam et al. 2004). The chemical extraction methods include three steps: Deproteination, demineralization and decoloration.

\section{Chemical deproteination}

The deproteination step includes the disruption of chemical bonds between proteins and chitin which involves the use of chemicals to depolymerize the biopolymer. For biomedical use, the removal of proteins is principally important, as the protein content is the chief culprit to bring allergy to the human population. The first approach used in deproteination was chemical method. A wide variety of chemicals were used and tested for their efficiency as deproteination reagents. Though, in each study, reaction conditions differ extensively. At concentrations ranging from 0.125 to $5.0 \mathrm{M}$, $\mathrm{NaOH}$ (a preferential reagent) was employed at varying temperature and treatment duration. $\mathrm{NaOH}$ not only leads to deproteination but also results in hydrolysis of biopolymer, dropping of its molecular weight and partial deacetylation of chitin.

\section{Chemical demineralization}

Removal of minerals, primarily calcium carbonate, is called as demineralization. It is commonly accomplished by acid treatment using sulphuric acid, hydrochloric acid, nitric acid, acetic acid and formic acid (Percot et al. 2003). Hydrochloric acid is the superior reagent among all these acids. Demineralization involves decomposition of calcium carbonate into calcium chloride along with the discharge of carbon dioxide as shown:

$$
2 \mathrm{HCl}+\mathrm{CaCO}_{3} \rightarrow \mathrm{CaCl}_{2}+\mathrm{H}_{2} \mathrm{O}+\mathrm{CO}_{2} \uparrow
$$

\section{Decoloration}

A decoloration step is an additional step which is required only if a colorless product is desired. An organic solvent mixture or acetone was employed to eliminate pigments like carotenoids (Dhillon et al. 2013; Benhabiles et al. 2012; Abdulkarim et al. 2013; Mohammed et al. 2013). Table 1 illustrates some of the key studies for recovery of chitin from marine resources through chemical (and in some cases combined with enzymatic) method. 
Table 1 Chemical extraction methods for recovery of chitin

\begin{tabular}{|c|c|c|c|c|}
\hline S. no & Method & Type of conditions & Properties of recovered chitin & References \\
\hline 1. & Chemical + enzymatic & $\begin{array}{c}\text { DM: } 1.5 \mathrm{M} \mathrm{HCl} \text {, ratio } 1: 10 \text {, at } 50^{\circ} \mathrm{C} \text { for } 6 \mathrm{~h}, \mathrm{DP}: \mathrm{A} 21 \text { pro- } \\
\text { tease enzyme/substrate } 7,75 \mathrm{U} / \mathrm{mg}\left(60^{\circ} \mathrm{C}, 6 \mathrm{~h}\right)\end{array}$ & $88 \%$ deproteinated & Younes et al. (2012) \\
\hline 2. & Chemical + enzymatic & $\begin{array}{l}\text { DM: } 0.55 \mathrm{M} \mathrm{HCl} \text {, ratio of } 1: 10(\mathrm{~W} / \mathrm{v}) \text { at room temperature } \\
\text { DP: B. mojavensis A21 crude protease }\left(3 \mathrm{~h}, 50^{\circ} \mathrm{C}, \mathrm{pH} 9.0\right)\end{array}$ & $\begin{array}{l}\text { Degree of acetylation was } 88.5 \% \\
\text { (shrimp) and } 78.6 \% \text { (crab shell) }\end{array}$ & Hajji et al. (2014) \\
\hline 3. & Chemical & $\begin{array}{l}\text { DM: } 1 \mathrm{M} \mathrm{HCl} \text {, ratio 1:30, } 75 \text { min at room temperature } \\
\text { DP: } 3 \mathrm{M} \mathrm{NaOH} \text {, ratio 1:30, } 75 \text { min at room temperature }\end{array}$ & & Srinivasan et al. (2018) \\
\hline 4. & Chemical + enzymatic & $\begin{array}{l}\text { DM: } 1.5 \mathrm{M} \text { of } \mathrm{HCl}\left(50^{\circ} \mathrm{C}, 2 \mathrm{~h}\right) \\
\text { DP: Alcalase }\left(50^{\circ} \mathrm{C}, 3 \mathrm{~h}\right)\end{array}$ & $80 \%$ deproteinated & Abdelmalek et al. (2017) \\
\hline 5. & Chemical & $\begin{array}{l}\text { DM: } 1.0 \mathrm{M} \mathrm{HCl}\left(35^{\circ} \mathrm{C}, 30 \mathrm{~min}\right) \\
\mathrm{DP}: 2.0 \mathrm{M} \mathrm{NaOH}\left(80^{\circ} \mathrm{C}, 20 \mathrm{~h}\right)\end{array}$ & $82 \%$ degree of acetylation & Yong et al. (2018) \\
\hline
\end{tabular}

$D M$ demineralization, $D P$ deproteination

\section{Biological extraction}

The development and progress of green extraction processes are centered on the concept of 'green chemistry' which is gaining more attention, preferring the application of microorganisms and enzymes for recovery of chitin. Conventionally, chemical extraction process is used for chitin extraction which involves demineralization, deproteination and deacetylation steps using concentrated acids and alkali under high-temperature conditions. Such process conditions require high energy and are associated with several negative implications such as increase in chitin purification cost and impaired physiochemical properties of extracted product (Dhillon et al. 2013). Therefore, use of biological process for chitin extraction is gaining immense attention as it is cleaner, eco-friendly and economic along with production of chitin and chitosan with desired properties. Khanafari et al. (2008) reported a comparative study on shrimp shells for removal of chitin by biological and chemical processes. The outcomes indicated that the biological extraction process was superior to the chemical method, since it not only preserved the chitin structure but also was eco-friendly. Deproteination of shrimp shells can also be achieved through biological method by employing proteolytic microorganisms. The biological extraction of chitin offers simpler manipulation, lower energy input and greater reproducibility in comparatively less time and solvent consumption (Dhillon et al. 2013).

The two most commonly used biological methods for chitin extraction include: (1) Enzymatic deproteination and (2) fermentation using microorganisms (Arbia et al. 2013; Gortari and Hours 2013).

\section{Enzymatic deproteination}

Proteolytic enzymes such as proteases are required for removal of proteins during chitin extraction from seafood waste. Plants, animals and microbes are the main sources of proteolytic enzymes. Various proteases like papain, trypsin, pepsin, devolvase, alcalase and pancreatin may be employed to remove proteins from shells and minimize the depolymerization and deacetylation during isolation of chitin. Accessibility for the enzymes can be modified by performing the deproteination either before or after demineralization step. In deproteination step, both crude and purified extracted enzymes can be used. However, purified enzymes are expensive in comparison to crude enzymes. Crude enzymes are mostly obtained from fish viscera and bacteria. Among these, bacterial proteases are more common. In majority of fish producing countries, $50 \%$ of by-product represents seafood harvest which is not utilized, discarded and rejected as waste (Rao et al. 1998). Therefore, it could be fascinating to employ crude enzymes for extraction of chitin to lower the cost of the process along with conserving the environment. Various studies have shown the use of bacterial proteases for carrying out deproteinization. Synowiecki and Al-khateeb (2000) carried out enzymatic deproteinization of shrimp waste which was already demineralized to obtain a nutritionally valuable protein hydrolysate and chitin.

Though, the enzymatic method is a clean process; however, the efficiency is lower in comparison to the chemical processes as around 5\%-10\% remaining protein still remained associated with the isolated chitin. Additional $\mathrm{NaOH}$ treatment could be used for treating final isolated chitin to increase its purity. In addition, the order of deproteinization and demineralization does not have significant influence on the yield and the quantity of the final chitin product in chemical process (Kaur and Dhillon 2015).

\section{Fermentation}

By carrying out deproteinization using fermentation method, the price of using enzymes can be reduced by adding selected microbial strains and endogenous 
microorganisms. Microbial strains can be selected by fermentation which can be single-stage, two-stage, successive fermentation or co-fermentation (Arbia et al. 2013). Fermentation approaches can be categorized into two main classes: lactic acid fermentation and non-lactic acid fermentation.

Lactic acid fermentation Lactobacillus sp. strain is used for fermentation of crustacean shells which produce proteases and lactic acid. Lactic acid is obtained by alteration of glucose which brings about a decline in $\mathrm{pH}$ of silage thereby subduing the growth of spoilage microbes. The productivity of lactic acid fermentation depends on various factors viz. the quantity and microbial composition of inoculum, initial $\mathrm{pH}, \mathrm{pH}$ progression during fermentation, carbon source and its concentration, temperature and the length of fermentation time (Prameela et al. 2010).

Non-lactic acid fermentation Both fungi and bacteria such as Bacillus sp. (Sini et al. 2007; Ghorbel-Bellaaj et al. 2012a, b), Pseudomonas sp. (Ghorbel-Bellaaj et al. 2011) and Aspergillus sp. (Mahmoud et al. 2007) were used for fermentation of crustacean shells in non-lactic acid fermentation. Several aspects were described to affect the fermentation process and thereby deproteinization and demineralization competences (Choorit et al. 2008). Ghorbel-Bellaaj et al. (2011) screened the influence of enzyme-substrate ratio and varying reaction time deproteinization efficacy of protease isolated from $P$. aeruginosa A2.

Table 2 illustrates the studies regarding biological extraction methods for recovery of chitin.

\section{Conversion of chitin into chitosan}

Chitin can be transformed into chitosan by employing enzymatic or chemical method (Tokuyasu et al. 2000; Philibert et al. 2017). Due to suitability for mass production, chemical processes are used commonly for the chitosan production at commercial scale.

In chemical method of deacetylation, either alkalis or acids are employed to deacetylate chitin. Since glycosidic bonds are quite vulnerable to acid, alkali is proposed to be a better choice (Hajji et al. 2014). Deacetylation of chitin can be carried out either heterogeneously or homogeneously. In the heterogeneous process, chitin is subjected to exposure with hot concentrated $\mathrm{NaOH}$ solution for few hours and an insoluble filtrate of chitosan is obtained in the form of $\sim 85 \%-99 \%$ deacetylated chitin. In the homogeneous process, alkali chitin is prepared after dispersing

Table 2 Biological extraction methods for recovery of chitin

\begin{tabular}{|c|c|c|c|c|c|}
\hline S. no & Source & Microorganism & Type of conditions & Outcomes & References \\
\hline 1. & Shrimp waste & Natural probiotic & $\begin{array}{l}\text { 72-h incubation, 5\% inocu- } \\
\text { lum level, 15\% glucose } \\
\text { concentration }\end{array}$ & $\begin{array}{l}\text { Rate of deproteination: } 89 \% \text {, } \\
\text { rate of demineralization: } \\
69 \%\end{array}$ & Prameela et al. (2010) \\
\hline 2. & Shrimp waste & Pseudomonas aeruginosa A2 & $\begin{array}{l}\text { Temperature } 60^{\circ} \mathrm{C} \text { and } \mathrm{pH} \\
8.0 \mathrm{DM} 3 \mathrm{~h} \text { hydrolysis at } \\
40^{\circ} \mathrm{C}\end{array}$ & Rate of deproteination: 56\% & Ghorbel-Bellaaj et al. (2011) \\
\hline 3. & Shrimp waste & $\begin{array}{l}\text { Lactobacillus plantarum PTCC } \\
\text { 1058- }\end{array}$ & $\begin{array}{l}\text { Medium-shrimp shell } \\
\text { powder ( } 5 \% \text { w/v), peptone, } \\
\text { yeast extract, meat extract, } \\
\mathrm{K}_{2} \mathrm{HPO}_{4} \text {, Na-acetate, } \\
\left(\mathrm{NH}_{4}\right)_{2} \text {-citrate, }\end{array}$ & $\begin{array}{l}\text { Rate of demineralization: } \\
\quad 82 \%\end{array}$ & Khorrami et al. (2011) \\
\hline 4. & Shrimp waste & Lactobacillus plantarum 1058 & $\begin{array}{l}5 \% \text { of seed culture, fermenta- } \\
\text { tion at } 30^{\circ} \mathrm{C}, 180 \mathrm{rpm}, \\
6 \text { days }\end{array}$ & $\begin{array}{l}\text { Rate of deproteination: } 45 \% \text {, } \\
\text { rate of demineralization: } \\
55 \%\end{array}$ & Khorrami et al. (2012) \\
\hline 5. & Crab waste & Lactobacillus sp. B2 & $\begin{array}{l}1\left(\mathrm{vv}^{-1} \%\right) \text { of Lactobacillus sp. } \\
\text { B2 } 30^{\circ} \mathrm{C}, 200 \mathrm{rpm}, 120 \mathrm{~h}\end{array}$ & $\begin{array}{l}\text { Rate of deproteination: } 56 \% \text {, } \\
\text { rate of demineralization: } \\
88 \% \text {, chitin purity } 34 \%\end{array}$ & Flores-Albino et al. (2012) \\
\hline 6. & Shrimp waste & Bacillus licheniformis & $\begin{array}{l}5 \% \text { (w/v) glucose, initial pH 7, } \\
5 \text { days at } 37^{\circ} \mathrm{C}, 200 \mathrm{rpm} .\end{array}$ & $\begin{array}{l}\text { Rate of demineralization: } \\
\quad 55 \%\end{array}$ & Ghorbel-Bellaaj et al. (2012a, b) \\
\hline 7. & Shrimp waste & B. cereus SV1 & $\begin{array}{l}5 \% \text { (w/v) glucose, initial } \mathrm{pH} 7 \\
5 \text { days at } 37^{\circ} \mathrm{C}, 200 \mathrm{rpm} \text {. }\end{array}$ & $95 \%$ rate of deproteination & Ghorbel-Bellaaj et al. (2012a, b) \\
\hline 8. & $\begin{array}{l}\text { Crab, shrimp, } \\
\text { prawn, krill } \\
\text { and lobster }\end{array}$ & $\begin{array}{l}\text { Bacillus licheniformis NRS- } \\
\text { 1264, Bacillus subtilis } \\
\text { B-59994 }\end{array}$ & $\mathrm{pH} 7,40 \pm 1^{\circ} \mathrm{C}, 150 \mathrm{rpm}$ & $\begin{array}{l}\text { Rate of demineralization: } \\
\quad 62.5 \%\end{array}$ & Pachapur et al. (2016) \\
\hline 9. & Shrimp waste & Pseudomonas aeruginosa & $\begin{array}{l}20 \% \text { glucose, } 20 \% \text { inocula- } \\
\text { tion and } 6 \text { days fermenta- } \\
\text { tion }\end{array}$ & $\begin{array}{l}\text { 82\% demineralization, } 92 \% \\
\text { deproteinization, chitin } \\
\text { yield: } 47 \%\end{array}$ & Sedaghat et al. (2017) \\
\hline
\end{tabular}


chitin in concentrated $\mathrm{NaOH}$ solution at $25^{\circ} \mathrm{C}$ for $3 \mathrm{~h}$. The alkali chitin is then suspended in crushed ice at $0{ }^{\circ} \mathrm{C}$. This process usually leads to production of soluble chitosan with $48 \%-55 \%$ of an average degree of acetylation. After $580 \mathrm{~h}$, this method results in production of chitosan having deacetylation degree of $10 \%$ with homogenously dispersed acetyl groups along the chains. Aiba (1991) revealed that under heterogeneous conditions, deacetylation reaction results in an uneven distribution of D-glucosamine and $N$-acetyl-D-glucosamine residues along the polymeric chains. Therefore, the degree of aggregation and solubility of chitosan may differ in aqueous solutions resulting in alteration of their characteristics. Moreover, distribution of acetyl groups along the polymeric chains, degree of deacetylation, molecular weight and viscosity in solution may change due to difference in conditions of chitosan preparation (Berger et al. 2005). Several factors during the deacetylation reaction can influence the characteristics of resulted chitosan product. Rege and Block (1999) examined the impact of processing time, temperature and mechanical forces on characteristics of chitin. The observations indicated that temperature and processing time were the most significant factors having noteworthy impact on degree of deacetylation and molecular weight. Tsaih and Chen (2003) also studied the effect of temperature and reaction time. All of these studies were carried out using the conventional one-factor-ata-time approach. These studies specified that molecular weight and deacetylation of chitosan are principally influenced by the concentration of $\mathrm{NaOH}$, temperature, duration of reaction and recurrence of alkaline treatment steps. More studies regarding the conversion of chitin into chitosan have been summarized in Table 3.

The enzymatic method of chitosan preparation includes deacetylation of chitin in the presence of chitin deacetylase enzyme. Chitin deacetylase (EC 3.5.1.41) is a member of carbohydrate esterase family and hydrolyzes the acetamido group present in the $\mathrm{N}$-acetylglucosamine units of chitin, thereby generating glucosamine units and acetic acid (Zhao et al. 2010). Enzymatic deacetylation of chitin was investigated with deacetylase isolated from various organisms such as fungi ( $A$. niger, $F$. velutipes, $C$. lindemuthianum, $M$. racemosus, etc.), insects (Apis mellifera, Drosophila melanogaster, Helicoverpa armigera, etc.) and bacteria ( $V$. cholera and other bacteria of Vibrionaceae family). However, chitin deacetylase was observed to be less effective for natural chitin which is insoluble and crystalline in nature. To enhance the accessibility of chitin deacetylase to acetyl groups of natural crystalline chitin, pretreatment is needed to carry out with physical or chemical methods such as sonication, grinding, heating and derivatization (Zhao et al. 2010).

Table 3 Methods of conversion of chitin to chitosan

\begin{tabular}{|c|c|c|c|c|}
\hline S. no & Method & Type of conditions & $\begin{array}{l}\text { Deacetylation } \\
\text { degree (\%) }\end{array}$ & References \\
\hline 1. & Chemical & $12.5 \mathrm{M} \mathrm{NaOH}\left(140^{\circ} \mathrm{C}\right.$ for $\left.4 \mathrm{~h}\right)$ & & Hajji et al. (2014) \\
\hline 2. & Chemical & Soaking in $18 \mathrm{M} \mathrm{NaOH}(24 \mathrm{~h})$, Heating $\left(90^{\circ} \mathrm{C}\right.$ for $\left.7 \mathrm{~h}\right)$ & 94.9 & Ma et al. (2015) \\
\hline 3. & Chemical and microwave irradiation & $50 \% \mathrm{NaOH}, 8 \mathrm{~min}$ irradiation at $350 \mathrm{~W}$ & 82.7 & Knidri et al. (2016) \\
\hline 4. & Ultrasound-assisted chemical method & $\begin{array}{l}\text { 40\% } \mathrm{NaOH} \text {, alternate irradiation (45 min) and non-irradiation } \\
\text { (30 min) periods }\end{array}$ & 77.9 & Birolli et al. (2016) \\
\hline 5. & Ultrasound-assisted chemical method & $\begin{array}{l}\text { Ultrasound-assisted deacetylation chitin in } 40 \% \mathrm{NaOH}(50 \mathrm{~min} \text {, } \\
60^{\circ} \mathrm{C} \text { ) }\end{array}$ & 95 & Fiamingo et al. (2016) \\
\hline 6. & Chemical & Soaking chitin in $50 \% \mathrm{NaOH}$ and autoclaved & 88 & Sedaghat et al. (2017) \\
\hline 7. & Chemical & $50 \% \mathrm{NaOH}\left(90^{\circ} \mathrm{C}, 30 \mathrm{~h}\right)$ & 74 & Yong et al. (2018) \\
\hline
\end{tabular}

The physiochemical properties of chitin and chitosan have been summarized in Table 4

Table 4 Physiochemical properties of chitin and chitosan

\begin{tabular}{llll}
\hline S. no & Properties & Chitin & Chitosan \\
\hline 1 & Structure & Poly-(2-acetamido-2-deoxy-D-glucose) & Poly-(2-amino-2-deoxy-D-glucose) \\
2 & Deacetylation degree $(\%)$ & $<50$ & $80-95$ \\
3 & Molecular weight $(\mathrm{kDa})$ & $100-1000$ & $20-750$ \\
4 & Solubility & Less soluble & More soluble \\
5 & Reactive groups & Hydroxyl and carboxyl groups & Amino and hydroxyl groups \\
\hline
\end{tabular}




\section{N-Acetyl glucosamine}

$\mathrm{N}$-Acetyl glucosamine (GlcNAc) is a widely distributed monosaccharide derivative of glucose and the monomeric unit of chitin. Apart from chitin, GlcNAc also constitutes heterogenous polysaccharides such as murein, hyaluronic acid, etc. (Ashry and Aly 2007). GlcNAc molecules and its derivatives with varied functional groups are involved in cell interactions (Chen et al. 2010). For example, GlcNAc is the prime component of $\mathrm{H}$ antigen in $\mathrm{ABO}$ blood groping and involves in antigen-antibody interaction. GlcNAc is also constituent of many glycoproteins in human such as mammalian growth factor, tissue plasminogen factor, hormones viz. follicle stimulating hormone, thyroid stimulating hormone, luteinizing hormone, human gonadotropic hormone, etc. (Chen et al. 2010).

GlcNAc can be extracted using chitin as feedstock through chitin hydrolysis. Chitin hydrolysis can be attained using either chemical hydrolysis or enzymatic method. In chemical method, chitin degradation is performed using a strong acid. The concentration of acid and reaction temperature should be in the range of $15-36 \%$ and $40-80{ }^{\circ} \mathrm{C}$, respectively (Bohlman et al. 2004). Conventionally, GlcNAc is commercially produced via acid hydrolysis method. However, the production of chemical waste, high cost and low yield are the limiting factors of chemical method which makes it less desirable.

The alternative enzymatic method involves chitinolytic enzymes and the process can be carried out under mild conditions. The chitinolytic enzymes comprise of endochitinases, exochitinases, chitobiase and $N$-acetylglucosaminidases (NAGases) (Gooday 1990). Endochitinases cleave chitin at internal sites, thereby generating low-molecular weight chitin oligosaccharides (COG), while exochitinases or chitobiases catalyze the progressive release of dimers by cleaving chitin at external sites (Fig. 5). Finally, the dimers and oligomers produced by endochitinases, exochitinases and chitobiases are degraded by NAGase (Lee et al. 1999). Enzymatic hydrolysis can be performed on industrial scale by mass production of chitonolytic enzyme by employing microorganisms such as Trichoderma hamatum, Trichoderma viride, Aspergillus niger, Carica papaya, Aeromonas hydrophila, etc. (Sashiwa et al. 2001). However, purification of enzymes from fermentation broth will increase the production cost.

\section{Preparation of nanostructured chitin and chitosan Top-down approach}

In the field of nanofabrication, the top-down approach refers to fabrication of a nanostructure from native superstructure of larger size through successive disintegration

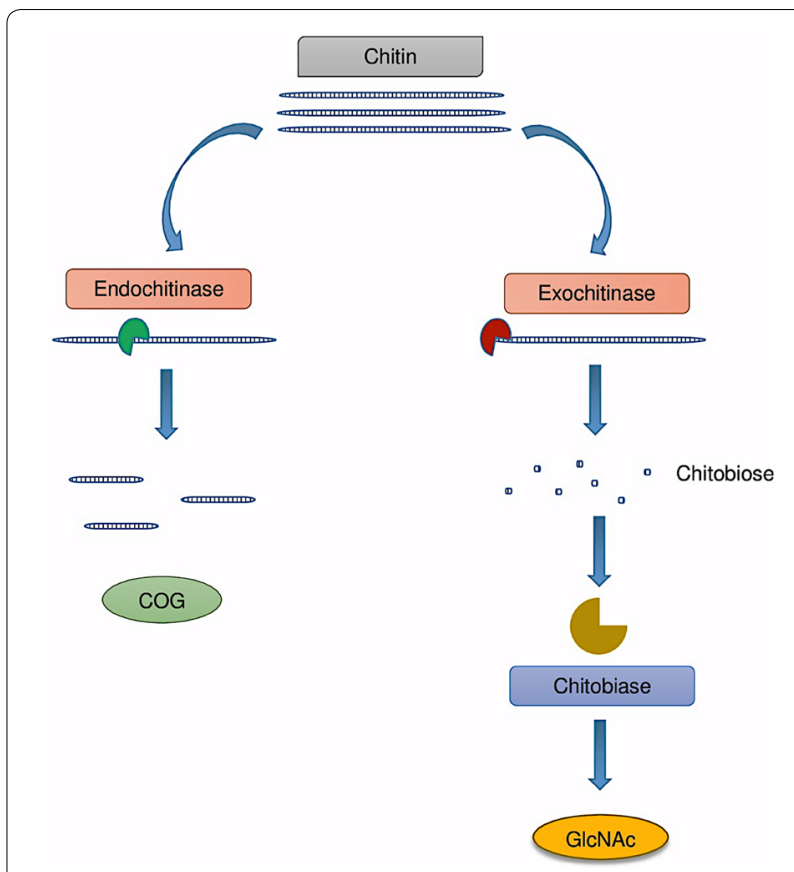

Fig. 5 Enzyme system for degradation of chitin into COG, chitobiose and GICNAC

(Iqbal et al. 2012). Several reports have been published on fabrication of chitosan nanofibers and nanowhiskers by adopting the method of disassembly (Liu et al. 2011a, b; Zhou and Wu 2011). The fabrication strategy was based on wet grinding of chitosan flakes which subsequently followed by homogenization at high pressure. The method resulted in achieving chitin nanofibres with diameter ranging from 100 to $1000 \mathrm{~nm}$. Wijesena et al. (2015) prepared chitin nanofibrils (average diameter of $5 \mathrm{~nm}$ ) from crab shells using ultrasonic method for mechanical disassembly. Subsequently, chitosan nanofibers were fabricated employing these chitin nanofibers as precursor. Similarly, researchers have also adopted the simple technique of grinding to fabricate chitin nanofibrils from microfibrils (Ifuku et al. 2013). In another study, chitin nanowhiskers and nanofibers were formed by radical assisted oxidation of chitin using 2,2,6,6-tetramethyl piperidine-1-oxyl followed by ultra-sonication (Fan et al. 2009). Tanaka et al. (2014) reported nanofibrillation of chitin powder by bubble formation with nitrogen gas under ultrasonication.

\section{Bottom-up approach of self-assembly}

Chitin nanofibers are conventionally produced by either top-down approach (breaking down the larger molecules) or by electrospinning of chitin solutions (Kadokawa 2015). Both approaches involve harsh conditions comprising use of highly acidic or basic solutions. However, recent researches focus on alternative 
environment-friendly approach to produce chitin/chitosan nanofibers by employing self-assembly mechanism. However, chitosan nanoparticles cannot self-assemble from pure chitosan due to its insolubility (Li et al. 2014). Therefore, amphiphilic chitosan derivatives solutions are used for self-assembly of chitosan nanoparticles. Chitosan-based amphiphilic copolymers are composed of hydrophilic and hydrophobic segments which undergo intermolecular association to form micelles ( $\mathrm{Li}$ et al. 2014). Self-assembly is a cost-effective bottom-up approach without needing vigorous chemical reactions. Figure 6 depicts the comparison of top-down and bottom-up approaches of chitin nanofabrication. Recently, curcumin-encapsulated chitosan nanoparticles were prepared by employing sonication method. Physicochemical parameters such as particle size, zeta potential and drug encapsulation were also evaluated. The results revealed

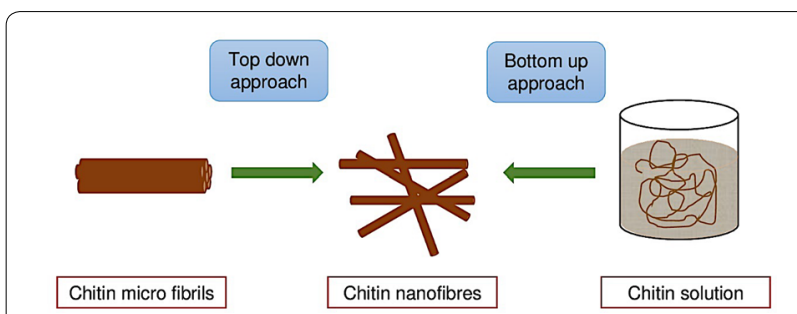

Fig. 6 Top-down and bottom-up approaches of chitin nanofibers preparation improved solubility of curcumin with sustained release pattern (Raja et al. 2016).

The absence of environmental implications and less complexity of fabrication process of self-assembled nanoparticles provide an attractive and economic alternative for conventionally prepared nanoparticles. However, controlling and manifesting desired properties, shape and size is still a challenging aspect.

\section{Blending of chitin and chitosan with other biopolymers}

To increase the mechanical properties of chitin and chitosan, they are often combined with PLA (Polylactic acid), PLGA (polylactic-glycolic acid), collagen alginate, etc. These composite biomaterials are processed to form scaffolds, films, sponges, fibers, gels, etc. with better mechanical properties. Table 5 summarizes the studies reporting preparation and application of chitinbased scaffolds blended with other biopolymers. Wang et al. (2008) investigated the bone repair capability of chitin-collagen-based scaffolds and witnessed repair of bone defect sites in rabbit after 12 weeks of implantation. Similarly, scaffolds incorporated with alginate along with chitin increase the vascularization and help in the deposition of the calcified matrix and connective tissue in scaffolds structure. To improve mechanical properties, chitin-based scaffolds were reinforced with PLGA which revealed compressive moduli and strength comparable to

Table 5 Studies related to chitosan blends and their application

\begin{tabular}{|c|c|c|c|c|}
\hline S. no & Scaffold & Host and targeted defects & Outcomes & References \\
\hline 1 & Chitosan + COG + PLGA & Skin defects in rats & $\begin{array}{l}\text { Superior healing and greater expres- } \\
\text { sion of } I H C \text {, higher mechanical } \\
\text { properties }\end{array}$ & Wang et al. (2013) \\
\hline 2 & Chitosan membrane + COG & Human skin defects & $\begin{array}{l}\text { Enhanced regeneration of skin } \\
\text { wounds after } 14 \text { days }\end{array}$ & Sarkar et al. (2013) \\
\hline 3 & Chitosan + silk fibroin & $\begin{array}{l}\text { Sciatic nerve defects of adult } \\
\text { Sprague-Dawley rats }\end{array}$ & Better nerve tissue regeneration & Gu et al. (2014) \\
\hline 4 & Chitosan + gelatin & Skin injuries of rabbit & $\begin{array}{l}\text { Adequate cytocompatibility in vitro, } \\
\text { inflammation was exhibited in vivo }\end{array}$ & Han et al. (2014) \\
\hline 5 & $\begin{array}{l}\text { Chitosan + cellulose + silver nano- } \\
\text { particles }\end{array}$ & Skin injuries in the backs of Wistar rats & $\begin{array}{l}\text { Efficient in the regeneration of skin } \\
\text { wounds }\end{array}$ & Ahamed et al. (2015) \\
\hline 6 & Chitosan + silk fibroin + HAP & $\begin{array}{l}\text { Subcutaneous tissue of 6-8-week-old } \\
\text { rat }\end{array}$ & Induced osteogenic differentiation & Shalumon et al. (2015) \\
\hline 7 & Chitosan + gelatin & Subcutaneous tissue of mice & Enhanced bone-like tissue formation & Ji et al. (2015) \\
\hline 8 & Chitosan sponges + copper & Calvarial defects in rats & Augmented bone neoformation & D’Mello et al. (2015) \\
\hline 9 & Chitosan + alginate & subcutaneous tissue of mice & Boosted osteogenic differentiation & Caridade et al. (2015) \\
\hline 10 & Chitosan + citric acid & tibial defects of rabbits & $\begin{array}{l}\text { Prompted bone regeneration and } \\
\text { adequate cytocompatibility }\end{array}$ & Ghosh et al. (2015) \\
\hline 11 & $\begin{array}{l}\text { COG + chitosan + PLGA + polyure- } \\
\text { thane }\end{array}$ & $\begin{array}{l}\text { implantation in skin lesions on the } \\
\text { backs of 2-month-old Sprague- } \\
\text { Dawley rats }\end{array}$ & $\begin{array}{l}\text { Improved regeneration of cutaneous } \\
\text { tissue wounds and better mechani- } \\
\text { cal performance }\end{array}$ & Wang et al. (2016) \\
\hline 12 & Chitosan + COG + HAP & $\begin{array}{l}\text { Implanted in calvarial defects of } \\
\text { 6-week-old mice }\end{array}$ & $\begin{array}{l}\text { Efficient bone regeneration and } \\
\text { repairing of defects }\end{array}$ & Xie et al. (2016) \\
\hline
\end{tabular}


the trabecular bone (Jiang et al. 2006). Nasrin et al. (2017) prepared chitin/PLA-laminated composite for implant application. Blending of $5 \%$ chitin in PLA revealed improved physical and mechanical properties along with lower water absorptivity and increased antimicrobial sensitivity. Bano et al. (2019) investigated the antibacterial and wound healing properties of glycerol-plasticized chitosan/PVA blends. Results revealed effective wound healing against second-degree burn along with normal growth of epidermis and accelerated connective tissue formation. Similarly, chitin and hydroxyapatite (HAP) composites have shown to enhance the mechanical properties of bone grafting materials, where the compressive strength of scaffolds increases with enhancing the percent composition of HAP in the composite structure. Chitin-polycaprolactone with HAP reported to show enhanced osteogenic differentiation (Arun Kumar et al. 2015). The in vitro osteogenic differentiation study revealed improved expression of bone-specific osteocalcin which is crucial for maturation and mineralization in osteogenic differentiation phases. Antibacterial properties of chitin/HAP scaffolds were also reported which may be attributed to the small size of scaffolds which is able to penetrate and disintegrate the bacterial cell membrane (Shakir et al. 2015). Chitin/Silk/HAP scaffolds were also prepared and reported to enhance new bone formation in human mesenchymal stem cells construct (Lai et al. 2015). Similarly, Zn-doped composite of chitosan and HAP exhibited noteworthy bone healing of rat bone defect within 14 days which indicate the efficacy of HAP in regeneration of bone (Dhivya et al. 2015). Bhowmick et al. (2015) prepared antibacterial macroporous chitosan/polyethylene glycol/HAP/ZnO scaffolds that showed cytocompatibility with osteoblast like MG-63 cells along with antibacterial effect against Escherichia coli, Bacillus cereus and Lysinibacillus fusiformis. Anirudhan and Parvathy (2018) prepared a drug carrier by blending thiolated chitosan and poly-ethylene glycol for releasing insulin. The monitoring of drug release revealed improved drug release profile with no negative implications. Giteru et al. (2019) optimized the preparation of zein-chitosan-polyvinyl alcohol composite by blending the polymers in varying percentage. Optimized film with the highest tensile strength was fabricated by blending $0.35,0.29,0.13$ and 0.23 (wt\%) of zein, chitosan, polyvinyl alcohol, polyethylene glycol, respectively.

Chitosan was also investigated as a conduit material for stimulating regeneration of nerve pertaining to its ability to support adhesion and proliferation of nerve cells, i.e., cerebral cortex cells, Schwann cells (Pearson et al. 2003). For nerve regeneration, the scaffolds should be made up of the biomaterial having a low young modulus, so that it can mimic soft nerve tissue. However, chitosan is comparatively more rigid and can compress and rupture the regenerating nerve cells. Therefore, some flexible molecules such as gelatin need to be incorporated in chitosan network before employing it for nerve repair (Cheng et al. 2003). Since pure chitosan-based conduits show the high appearance of inflammatory cells, some proteins or polymers need to be incorporated to reduce the inflammation (Yang et al. 2004; Pfister et al. 2007). Typically, chitosan should be modified by blending of adhesion molecules such as fibronectin, laminins and poly-L-lysine to increase the adhesion, proliferation, and growth of nerve cells which further facilitates the speedy retrieval of nerve functionality. However, the high cost of the adhesive additives limits their applicability. Therefore, collagen was combined with chitosan network of conduit material which showed improvement in nerve repair efficiency as compared to pure chitin-based conduit material (Wang et al. 2009). The differentiation percentage has also reported to be increased by a chitosan-collagen conduit in comparison to pure chitosan (Yang et al. 2009). Moreover, chitosan shows slow degradation rate in comparison to chitin which can be modulated by incorporating highly degradable material such as gelatin, collagen, etc. (Yang et al. 2009).

Apart from biomedical applications, chitin and chitosan blends were also explored for other applications. Rezakazemi et al. (2018) employed lignin and chitosan blend for removal of methylene blue dye from water effluent. Yin et al. (2018) prepared carboxymethyl chitosan/ poly(vinyl alcohol)/Cu blend film for packaging application. The tensile test and thermal gravimetric analysis revealed improved mechanical and thermal properties of chitosan after blending, while the copper ions loading improved the antibacterial activity.

\section{Hydrophobic modifications of chitin and chitosan}

Hydrophobic modification of chitin and its derivatives facilitates their self-assembly when immersed in polar solvents (Quiñones et al. 2018). The modification is accomplished by incorporation of hydrophobic chemical entities in the chitin polysaccharide chains. Chitosan modified with deoxycholic acid in such way was suggested as suitable delivery system for DNA transfection (Kim et al. 2001). Hydrophobic modification was carried through carbodiimide via formation of amide bond. The negatively charged DNA and positively charged chitosan nanoparticles resulted in micelle-like nanoparticle vehicle for gene delivery due to self-assembly. Self-aggregated nano-particles in the range of $130-300 \mathrm{~nm}$ were prepared by varying the ratio of chitosan and deoxycholic acid along with the molecular weight of chitosan.

Wang et al. (2007) prepared chitosan self-aggregates modified with cholesterol and investigated for 
encapsulating the anti-cancer drug epirubicin. Spherical nanoparticles entrapping epirubicin were ranged from 338 to $472 \mathrm{~nm}$. A slow and controlled release of epirubicin was observed. Another study investigated the encapsulation of retinoic acid in cholesterol-modified nanoparticles of chitosan and observed controlled release. Hu et al. (2006a, b) modified chitosan oligosaccharide with stearic acid for delivery of paclitaxel. $\mathrm{Hu}$ et al. (2009) allowed reaction of doxorubicin cis-aconitate with chitosan/stearic acid aggregate to investigate double functionalization of chitosan. The reaction resulted in micelle formation ranging from 40 to $106 \mathrm{~nm}$. Huang et al. (2015) modified chitin whiskers by reaction with bromohexadecane for application in structuring oil. The modified chitin whiskers were observed to remarkable thickening effect by forming stable dispersion in sunflower oil. Duan et al. (2014) modified chitin sponge with deposition of methyl trichlorosilane. The modified chitin sponge was observed to collect organics both on the surface and bottom of the water. It was able to absorb 58 times more than their weight absorption capabilities. Sun et al. (2018) modified chitin surface by employing 2,2,6,6-tetramethylpiperidine-1-oxyl radical with hypochlorite and sodium bromide. The process functionalized the chitin surface with carboxyl groups which enhanced the interaction between chitin and cadmium ions and enhanced the adsorption. Hai and Sugimoto (2018) modified the surface of chitin and chitosan by direct grafting of poly(3-hexylthiophene) through oxidative polymerization. The modified chitin and chitosan surface showcase high hydrophobicity with improved electrical properties. Yan et al. (2018a) modified the chitosan surface with succinyl, carboxymethyl and quaternary ammonium groups and observed the hemostatic properties of modified chitosan.

\section{Applications of chitin- and chitosan-based materials}

Adapting new approaches and advanced technologies to modernize the governing science and policies is needed call for betterment of humans and the environment. Regarding life science, the most advanced approach is the transitioning of materials from micro-/macro-scale to nano-scale. Utilizing chitin and chitosan extracted from waste resources as nanomaterial for various applications can maximize the resource productivity (Fig. 7).

\section{Carriers for active ingredients}

Chitin-based nanomaterials are used as carriers for cosmetic ingredients. Morganti et al. (2008) embedded chitin nanoparticles with antioxidants (lutein, melatonin, ectoine) which enhanced the penetration of active ingredients. Combining chitin with antioxidant ingredients

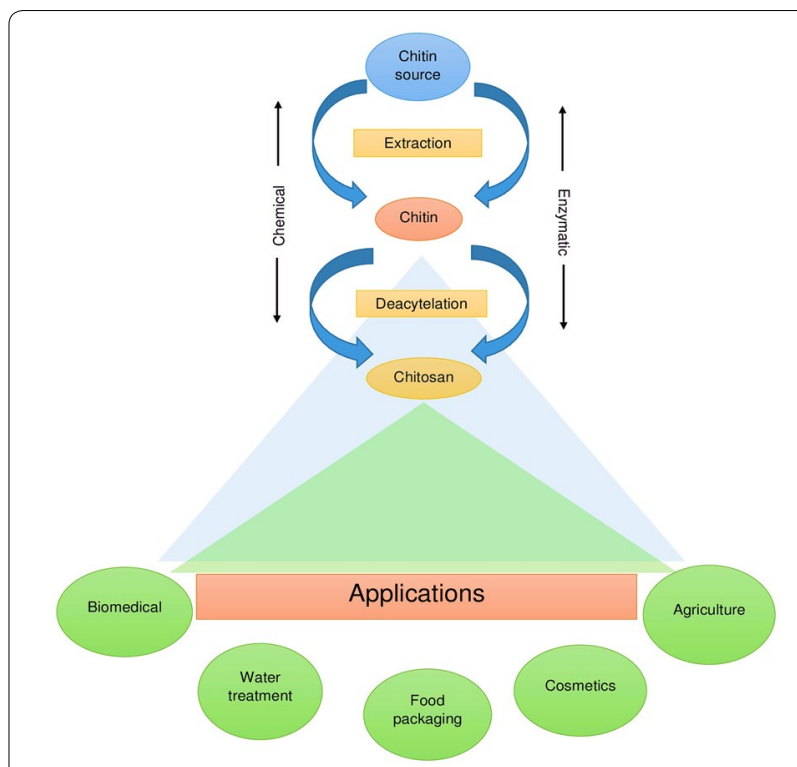

Fig. 7 Preparation of chitin and chitosan from natural resources and their applications

also helps to guard the skin from harmful effect of solar radiation due to the scavenging activity of chitin, thereby retarding the photo-aging effects and wrinkles. The chitin polymers are often employed in creams, makeup, lotions, hair care products such as shampoo, hair spray, hair colors and toothpaste, mouthwashes, etc. (Dutta et al. 2004; Gautier et al. 2008). Morganti et al. (2012) combined chitin nanofibrils with hyaluronic nanoparticles to improve the antioxidant activity of chitin. In vivo study was conducted for 60 days on 60 women suffering from photoaging after evaluating the safety concerns on keratinocytes and fibroblasts culture viability.

\section{Reinforcing material for tissue engineering}

Chitin nano-fibrils can be employed as a reinforcing material for synthesizing biodegradable nano-composites as scaffolds for tissue engineering (Morganti et al. 2008; Mincea et al. 2012). To regain or enhance functionality, some tissues or organs are required to be repaired or replaced by implanting tissue substitutes in the body. Tissue engineering process involves regenerative of new tissue growing on biomaterials acting as scaffolds in the presence of bioactive molecules such as cytokines and growth factors (Fig. 8) (Ribeiro et al. 2017). To receive appropriate outcomes, the scaffolds must be designed with proper architecture to trigger a desirable cellular response from targeted organ (Keeney et al. 2012; Agarwal et al. 2013). If the structure of scaffolds is comparable to the native extracellular matrix of the human body, it increases the cell adhesion differentiation and proliferation. Fabrication of scaffolds can be 


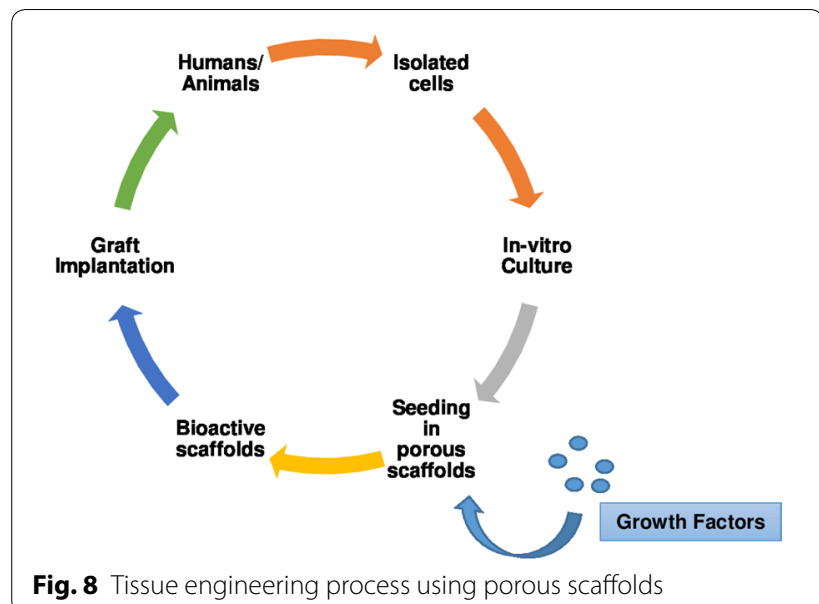

Fig. 8 Tissue engineering process using porous scaffolds

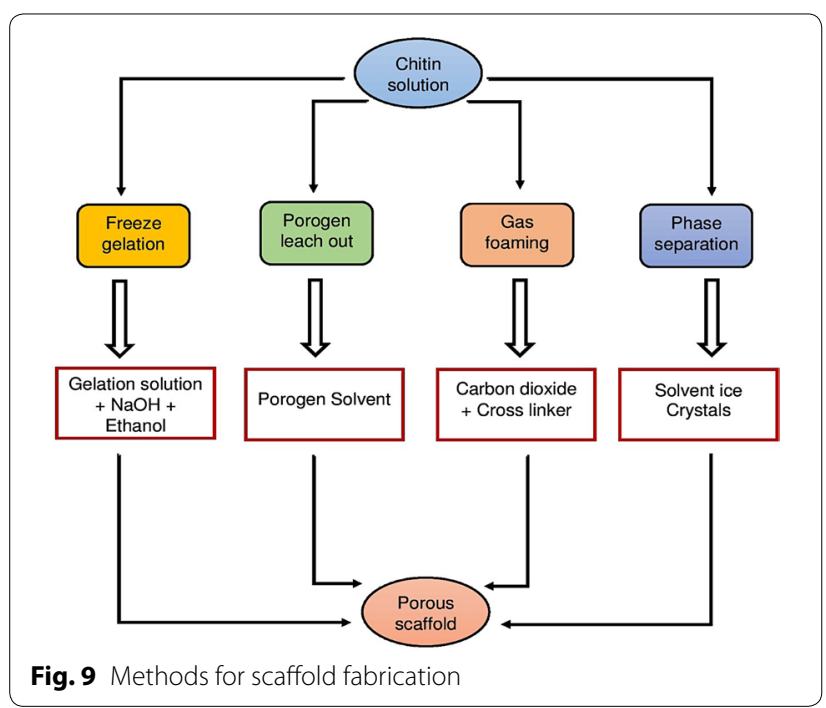

done by employing multiple methods such as gas foaming technique, particulate leaching technique, phase separation and lyophilization method, freeze gelation method, etc. (Fig. 9). In gas foaming method, gas bubbles are generated by mixing agent with pre-polymer. In an alternate method, polymer can be saturated at high pressure with subcritical and supercritical gas. Depressurization leads to bubbles growth which generates pores when the gas bubbles escape the solution (Levengood and Zhang 2014). Supercritical carbon dioxide is the most frequently employed for production of porous scaffolds. In freeze gelation method, the phase separated is subjected to sodium hydroxide or ethanol exposure at $-20{ }^{\circ} \mathrm{C}$ to induce gelation of chitosan. In phase separation method, chitosan solution made in acetic acid is introduced in mold and allowed to freeze. Ice crystals formed in solution after freezing are phase separated. The subsequent freeze drying step leads to formation of porous scaffolds pertaining to sublimation of ice crystals. In particulate leaching method, a porogen such as paraffin, gelatin, etc. is mixed with chitosan solution and subsequently leached out resulting in porous scaffold.

Another form of chitin, chitin whiskers also have a broad range of possible applications in biomedical field for preparing renewable and biodegradable nanoparticles and nanocomposites (Usman et al. 2016; Pangon et al. 2016). Pourhaghgouy et al. (2016) prepared nanocomposite scaffolds of chitosan reinforced with bioactive glass using freeze casting method. Concentration of bioactive glass ceramics was varied from 10 to $50 \%$, where fourfold increase in compressive strength was observed for 50\% concentration. Moatarya et al. (2017) prepared chitin-chitosan-nanodiopside composite scaffolds by employing freeze drying technique and reported enhanced swelling and degradation properties. The cytocompatibility was analyzed and no significant toxicity was observed. Silica derivatives such as $\mathrm{SiO}_{2}$ nanoparticles are incorporated in chitin/chitosan matrix to induce biomineralization. Lee and Kim (2016) performed in vivo study to investigate the healing properties of such $\mathrm{SiO}_{2}$-incorporated chitosan membranes in rats for recovering critical calvarial defect. The resultant improvement in healing process can be attributed to the accelerated osteoblast function induced by $\mathrm{SiO}_{2}$ nanoparticles.

\section{Excipients for active pharmaceutical ingredients}

Chitin-based environmentally sensitive smart drug delivery systems can be employed for site-specific controlled drug delivery based either on $\mathrm{pH}$ or temperature sensitivity. Being immensely hydrophilic in nature, chitosan can always be cross-linked and blended with other biodegradable polymers to yield desirable release rate of drugs. Recently, chitosan nanoparticles were employed to encapsulate levofloxacin for treating ocular infection and observed to be non-irritant for ocular administration (Ameeduzzafar et al. 2018). In another study, a polyelectrolyte complex formulated by combining chitosan and carboxylic curdlan was employed for delivery of 5-fluorouracil (Yan et al. 2018b). Recently, chitosan has also garnered attention as vaginal delivery of peptide-based vaccines and microbicides for treating sexually transmitted diseases (Marciello et al. 2017; Shariatinia 2019).

Chitosan can also be blended with PLA, PLGA, collagen, alginate, etc. for delivery of antibiotics, chemotherapeutics, anti-inflammatories, immunosuppressant, antipsychotics, vaccines, DNA, siRNA and proteins (Yang et al. 2009). Ding et al. (2015) coated chitosan with $\mathrm{Fe}_{3} \mathrm{O}_{4}$ nanoparticles as delivery system for anti-cancer drug 5-fluorouracil. 


\section{Water treatment}

Though activated carbon is still the first and foremost choice as adsorbent for waste water treatment, the lowcost and eco-friendly green adsorbent material prepared from natural resources is gaining attention. The ever increasing demand of fabricating sustainable and environment-friendly bio-based products from natural resources has further boosted the intensive research to shift towards green bio-adsorbents. Recently, cellulose and chitosan have been suggested as appropriate replacement for activated carbon as absorbents to remove impurities from waste water (Olivera et al. 2016). The presence of functional groups such as hydroxyl and amino group further makes chitosan more alluring as absorbent to remove metal pollutants and pesticides (Dehaghi et al. 2014). Several studies have investigated the efficacy of chitosan nanostructures for absorption of lead, chromium, cadmium, arsenic, acid green 27 dye etc. (Qi et al. 2004; $\mathrm{Hu}$ et al. 2006b; Seyedi et al. 2013; Sivakami et al. 2013; Kwok et al. 2014).

Raw native chitosan has been reported to have maximum adsorption capacity of $10 \mathrm{mg} / \mathrm{g}$ which is comparable to the adsorption capacity of activated carbon (10.3 mg/g) (Pyrzynska 2019). Combining chitosan and activated carbon in nanocomposites was reported to enhance the adsorption capacity as high as $52.63 \mathrm{mg} / \mathrm{g}$ (Hackbarth et al. 2015). Solid supported materials such as magnetic nanoparticles and bentonite were also reported to enhance the adsorption capacity of chitosan for removal of cadmium (Ahmad et al. 2015; Demey et al. 2018). Modification of chitosan surface with quaternary ammonium bromide was also reported for removal of heavy metal ions (Zhang et al. 2016; Shekhawat et al. 2017). The surfactant-modified chitosan beads prepared by Pal and Pal (2017) enhanced the adsorption of cadmium ions threefold as compared to pure chitosan.

The composites of chitosan with other biopolymers were also explored for dye removal application. Composite hydrogels of chitosan, rectorite and cellulose were investigated by Tu et al. (2017) as dye absorbents for Congo Red. Kyzas et al. (2015) prepared chitosan grafted with carboxylic groups and investigated their ability to remove zinc and cationic dye. Chitosan grafted with succinyl group revealed improved absorption and simultaneous removal of $\mathrm{Zn}$ and Remarcyl Red dye from wastewaters. A membrane filtration system equipped with chitosan nanoparticle-coated membrane was investigated for its water purifying ability. The multiple tube fermentation test revealed maximum elimination of coliforms (Rajendran et al. 2015). Chitosan composites blended with zinc oxide nanoparticles were reported to remove almost $99 \%$ of color pollutant present in the textile industry effluent (Abul et al. 2015).

\section{Antimicrobial agent}

The antimicrobial activity of chitin and its derivatives can be explored to designate them as food preservative that slows down the microbial deterioration of foodstuff (Barikani et al. 2014; Sethulekshmi 2014). Chitosan addition to cheese was investigated to analyze its effect on cheese deterioration (El-Diasty et al. 2012). The shelf life was reported to be extended by inhibiting the growth of yeast and molds.

Apart from being served as a food preservative, chitin and chitosan are also employed as antimicrobial coating and packaging due to the antimicrobial properties they possess. Fruits, vegetables, grains, fish, etc. can be coated with biofilms of chitosan that provides a protective barrier from microbial attack thereby preserving the nutritional quality of food (Aranaz et al. 2009; Sinha et al. 2014). Biopolymeric films of chitin in combination of other antimicrobial compounds such as bacteriocins, antibiotics, fungicides, chelating agents, plants extracts like thymol and cinnamaldehyde can also be employed to improve the shelf life of food by reducing food spoilage due to microorganisms (Dutta et al. 2012). The edible and biodegradable chitosan-based films used for food packaging can also be consumed along with packaged food.

Chitosan-based derivatives such as hydroxypropyl chitosan (HPCS) and diethoxyphosphoryl polyaminoethyl chitosan also possess antimicrobial activity similar to chitosan. Deng et al. (2013) immobilized nanofibrous mat with HPCS through electrospinning method and added organic rectorite to enhance the antibacterial activity. The prepared HPCS-based nanofibrous mats revealed superior antibacterial activity against $E$. coli and $S$. aureus. Fan et al. (2018) investigated the antifungal properties of diethoxyphosphoryl polyaminoethyl chitosan derivatives against $P$. capsici, F. solani, and B. cinerea. Both multi-aminoethyl groups and phosphoryl groups resulted in improved antifungal activity of chitosan.

Chitin- and chitosan-based food packaging products are manufactured and supplied worldwide. ChitoClear ${ }^{\circledR}$, a chitosan-based product for food packaging, is commercialized by Primex Company (Siglufjordur, Iceland). NorLife and Kitoflokk ${ }^{\mathrm{TM}}$ brand from Norwegian Chitosan (Kløfta, Norway) also manufactured for application in food and beverages (Ferreira et al. 2016).

\section{Anti-tumor agent}

Chitosan and its derivatives have been stated to exhibit antitumor activities both in vitro and in vivo (Tokoro et al. 1988). The in vivo investigations demonstrated the inhibitory effect of chitosan on tumor cells as an outcome of stimulation in T-lymphocyte proliferation arisen by the elevated secretion of interleukins. Chitosan was also reported to stimulate macrophages which suppressed the 
growth of tumor cells in mice (Nishimura et al. 1986). Several reports advocate the antitumor activity of chitosan, even when it is administered orally. Oral administration of chitosan along with diet at $1 \mathrm{mg}$ per $\mathrm{kg}$ of dose resulted in decrease of tumor growth in the liver by $62 \%$ (Guminska et al. 1996).

The antitumor activity of chitin and its derivative reportedly depends on the structural characteristics of chitin derivative (molecular weight and the degree of deacetylation) as well as the type of tumor cells. Jeon and Kim (2002) investigated the impact of varying the molecular weight of chitosan on the growth of uterine cervix carcinoma 14 (U14) and sarcoma 180 (S180) and revealed that the antitumor activity of chitosan increases with decreasing the molecular weight. Other researchers examined the impact of varying molecular weight on tumor cells in terms of cytotoxicity and observed no difference with changing molecular weight. However, better activity was observed with increasing the degree of acetylation in chitin derivatives (Younes and Rinaudo 2015).

Apart from chitin and chitosan, GlcNAc is also known to possess antitumor activity. The study conducted on tumor-bearing mouse model has reported to show significant tumor growth suppression after oral administration of GlcNAc (Masuda et al. 2014).

\section{International projects based on chitin and available patents}

Realizing the unique features and a wide range of potential applications of chitin, various international projects have been initiated in past decade in coordination with commercial sector to further explore the capabilities of chitin to dominate on industrial scale. This section summarizes some of the key projects initiated in this direction such as CHITOCLEAN, $n$-CHITOPACK and BIOMIMETIC project.

\section{CHITOCLEAN}

The CHITOCLEAN project coordinated by Austria was initiated for purification of polluted drinking waters by employing the holistic approach of water treatment based on chitin-based biosorbents which are known for their excellent absorption capabilities. The project demonstrated the power of chitin-based materials to remove the low-concentration pollutants. In this project, the water filters were created by employing shrimp and crab carcasses for domestic-scale applications as well as largescale applications. The project partners also investigated regeneration and recycling of chitin-based materials to enhance the working life of the filters. In addition, the effect of these filters on mineral contents of water was also investigated along with the methods of disposing the old filter material. New chitin-based biosorbents were found to show more adsorption properties in comparison to old original chitin-based materials, specifically for fluorides and nitrates (CORDIS 2018).

\section{n-CHITOPACK}

The $n$-CHITOPACK project coordinated by Mavi, Italy was initiated with the objective of developing new chitinbased food packaging material by utilizing chitin nanofibrils with other natural polymers (Morganti 2013). The projects targets towards finding the materials having bacteriostatic properties, $100 \%$ biodegradability, comparable mechanical properties with existing packaging materials. The strategy employed by Mavi was focused on developing new industrial applications of patented chitin nanofibrils raw materials for preparing biodegradable food packaging which were earlier limited to cosmetic products and medical devices. The project analyzed user's requirement through survey as well as analysis of market. The scientific analysis of chitin nanofibrils revealed the efficacy of chitin naofibrils for food packaging as well as safety (CORDIS 2018).

\section{Biomimetic}

The project was initiated in 2012 and coordinated by Procter \& Gamble, Italy. The project tried to mimic the enzymatic processes utilized by marine organism to develop bio-mimetic products. For example, the ability of mussels of showing strong surface adhesion in aqueous environment can be employed by conjugating the biomass-based precursors with chitin nanofibrils to develop biobased detergents, cosmetic products, etc. Despite a fair number of published studies on chitosan-based drug delivery systems, FDA has not approved any chitosanbased product for drug delivery. The currently available commercial products based on chitin and chitosan are summarized in Table 6 . BST-Gel ${ }^{\circledR}$ manufactured by Piramal Healthcare Canada Inc is a patented chitosanbased self-forming hybrid composite. The self-forming composite consists of two components-liquid (chitosan) and solid (minerals) which admixed to form an injectable pre-gelled paste. This paste eventually turns into gellike biomaterial in situ. The product finds application in chronic wound healing, cartilage repair, etc. (Chaput and Chenite 2014). ChitoFlex ${ }^{\circledR}$ PRO manufactured by Tricol biomedical Inc is also a hemostatic dressing material to control severe bleeding which also provide antibacterial activity for a wide range of pathogens (McCarthy et al. 2014). The dressing material is a freeze-dried chitosan product which forms adhesive material after coming in contact with flowing blood and adheres to tissue surface. Slim $\mathrm{MED}^{\mathrm{TM}}$ manufactured by Kitozyme consists of combination of non-animal chitosan and vitamin C. In acidic stomach conditions, chitosan binds with 
Table 6 Chitin-based commercial products and their applications

\begin{tabular}{|c|c|c|c|c|}
\hline S. no & Product & Manufacture & Application & Patent/references \\
\hline 1 & BST-Gel ${ }^{\circledR}$ & Piramal Healthcare Canada Inc & $\begin{array}{l}\text { Chronic wound healing, bone filling, } \\
\text { cartilage repair, invertebral disc } \\
\text { restoration }\end{array}$ & US 8747899, Chaput and Chenite (2014) \\
\hline 2 & ChitoFlex ${ }^{\circledR}$ PRO & Tricol biomedical Inc & $\begin{array}{l}\text { Wound dressing and controlling } \\
\text { bleeding }\end{array}$ & US 8668924 B2, McCarthy et al. (2014) \\
\hline 3 & Hemcon ChitoGauze ${ }^{\circledR}$ PRO & Tricol Biomedical Inc & Wound dressing & US 9205170 B2, Lucchesi and Xie (2015) \\
\hline 4 & Talymed $^{\circledR}$ & Marine polymer technologies & Wound dressing material & $\begin{array}{l}\text { US } 9139664 \text { B2, Finkielsztein and Vour- } \\
\text { nakis (2015) }\end{array}$ \\
\hline 5 & Protasan $^{\text {тм }}$ & NovaMatrix & Pharmaceutical application & WO 2015081304 A1, Francis et al. (2015) \\
\hline 6 & Reaxon ${ }^{\circledR}$ & Medovent & Nerve regeneration & Medovent (2018) \\
\hline 7 & Slim MED ${ }^{\mathrm{TM}}$ & Kitozyme & Treatment of excess weight & $\begin{array}{l}\text { US } 20040126444 \text { A1, D'huart and Dallas } \\
\text { (2004) }\end{array}$ \\
\hline 8 & Liposan Ultra ${ }^{\circledR}$ & Primex & Weight loss & US 6130321, Johnson and Nichols (2000) \\
\hline 9 & ChitoDot $^{\circledR}$ & Tricol biomedical Inc & $\begin{array}{l}\text { Wound dressing and controlling } \\
\text { bleeding }\end{array}$ & US 8269058 B2, McCarthy et al. (2012) \\
\hline
\end{tabular}

the fatty acids and forms chitosan lipid complex which get excreted thereby reducing the absorption of lipid in body (D'huart and Dallas 2004). Similarly, Liposan Ultra ${ }^{\circledR}$ is a chitosan-based dietary supplement manufactured by Primex, Iceland. Liposan Ultra ${ }^{\circledR}$ traps the fat and oil consumed in diet and reduces their absorption (Johnson and Nichols 2000). There are some companies such as West Pharmaceutical Services, Inc. which are running trials for chitosan-based drug delivery products also. Still, more studies related to clinical trials of chitosanbased drug delivery systems with appropriate precautions are required to get approval from FDA. Talymed ${ }^{\circledR}$ is a wound dressing material manufactured by Marine polymer technologies. It is an advanced bio-active matrix designed for healing the wounds including venous ulcers, diabetic ulcers, pressure ulcers, surgical wounds, seconddegree burns, etc. Protasan ${ }^{\mathrm{TM}}$ is a water-soluble chitosan glutamate salt manufactured by NovaMatrix. It may be used for a wide range of in vitro and in vivo applications including drug delivery, wound healing, bandages, artificial skin, plaque inhibitor, etc. Reaxon ${ }^{\circledR}$ is a nerve guide manufactured by Medovent to replace bone autografts. This chitosan-based nerve conduit is resistant to collapse and prevents nerve compression and sensitivity disorders caused by autografts. The electrostatic forces between the positively charged Reaxon ${ }^{\circledR}$ and negatively charged cell components support the nerve repair actively.

\section{Conclusions}

Being the second most abundant polymer after cellulose, chitin can be readily obtained from crustacean shells waste viz. crabs, shrimps, lobster, etc. and has a huge potential to meet consumer needs in various commercial sectors. However, use of harsh chemicals in extraction methods often results in the production of polymers with variable properties viz. size, molecular weight, charge, and degree of acetylation/deacetylation. Therefore, greener and cleaner processes, i.e., biological extractions need to be designed for extracting chitin by minimizing the amount of irregular by-products. Moreover, recovery of polysaccharides, proteins, minerals and pigments from these wasted by-products is also an appropriate solution to maintain ecological balance along with economical gain. Appealing characteristics of chitin and derivatives attract great deal of interest from scientific community to explore various paradigms of industrial applications where chitin can improve quality of existing conventional materials and services. Versatility of applications ranging from biomedicines, textile, food, pharmaceuticals to cosmetics made chitin a lucrative way to channel waste from marine food processing industry into valuable products. Despite potential of providing outstanding properties for commercial purposes, the industrial application of chitin in various sectors is still limited due to issues regarding optimization of mechanical and biological properties according to intended application. Therefore, intensive research is required for designing and optimization of processing methods of chitin into various forms and possible reinforced materials for controlling properties in desirable range.

\section{Future perspectives}

With wide range of potential applications in biomedical field as well as other commercial sectors, chitin-/ chitosan-based materials are expected to create major breakthroughs and new prospects for economic growth and development and health. The biological method for extracting chitin from seafood waste is a cost-effective 
and green process as no chemical is used compared to the chemical extraction. However, the biological method requires time and controlled fermentation conditions such as initial $\mathrm{pH}$, temperature, active culture, type and concentration of supplements, type and concentration of carbon and nitrogen sources, inoculum size, etc. Microbial contamination of the products obtained from biological extraction methods is another important aspect. Moreover, there is a lack of single-stage extraction process for obtaining pure chitin product as in most of the fermentation processes, the product contains large amount of protein which comes along with the deproteination process. It is further stated that the removal of this residual protein may be performed by chemical method.

Chitin/chitosan derivatives are promising candidates as biomaterials for wound healing, tissue engineering and drug delivery applications. Being fabricated from freely available natural resources, these biomaterials can be economically more feasible as compared to the synthetic polymer materials. Furthermore, their application in biomedical sector such as scaffolds for tissue engineering saves the cost and manpower required for a second surgery to remove them (as chitin/chitosan materials are biodegradable). The biocompatibility of chitin/chitosan materials also prevents the requirement of any treatments due to sensibility or rejection of implants fabricated from employing these materials. However, there are still many challenges regarding control of mechanical and physical properties of these materials. For nanomaterial application, potential risk of acute and chronic toxic effects is foremost challenge to face. Therefore, future chitin-based biomaterials must accomplish tissue regeneration with simultaneously reducing immune responses and chances of infections.

\section{Abbreviations \\ GlcNAc: N-acetyl glucosamine; NAGases: N-acetylglucosaminidases; COG: chitin oligosaccharides; PLA: polylactic acid; PLGA: polylactic-glycolic acid; HAP: hydroxyapatite; HPCS: hydroxypropyl chitosan.}

\section{Authors' contributions}

MY, PG developed the manuscript. KP, MK reviewed and corrected the manuscript for grammatical and syntax errors. NP provided scientific and technical comments to enhance the quality of manuscript. WV reviewed the manuscript and provided scientific inputs. All authors read and approved the final manuscript.

\section{Author details}

${ }^{1}$ Centre for Energy and Environment, Malaviya National Institute of Technology, Jaipur, Rajasthan 302017, India. ${ }^{2}$ Department of Microbiology, School of Life Sciences, Central University of Rajasthan Bandarsindri, Ajmer, Kishangarh, Rajasthan 305801, India. ${ }^{3}$ Department of Biotechnology, The IIS University, Jaipur, Rajasthan, India.

\section{Acknowledgements}

MY and KP thank MNIT Jaipur for scholarships and facilities. WV acknowledge the Department of Biotechnology, Ministry of Science and Technology (No. BT/RLF/Reentry/04/2013) Government of India for financial support.

\section{Competing interests}

The authors declare that they have no competing interests.

\section{Availability of data and materials}

The data presented in the manuscript were reviewed and concluded from the earlier reported studies and mostly presented in the form of text. All the figures in the manuscript have been drawn by the authors themselves.

\section{Consent for publication}

Not applicable.

\section{Ethics approval and consent to participate}

Not applicable.

\section{Funding}

The Department of Biotechnology, Ministry of Science and Technology Government of India supported this work financially (No. BT/RLF/Reentry/04/2013) provided to W.

\section{Publisher's Note}

Springer Nature remains neutral with regard to jurisdictional claims in published maps and institutional affiliations.

Received: 31 October 2018 Accepted: 4 February 2019

Published online: 08 February 2019

\section{References}

Aam BB, Heggset EB, Norberg AL, Sorlie M, Varum KM, Eijsink VG (2010) Production of chitooligosaccharides and their potential applications in medicine. Mar Drugs 8:1482-1517

Abdelmalek BE, Sila A, Haddar A, Bougatef A, Ayadi MA (2017) B-Chitin and chitosan from Squid gladius: biological activities of chitosan and its application as clarifying agent for apple juice. Int J Biol Macromol 104:953-962

Abdou ES, Nagy KSA, Elsabee MZ (2008) Extraction and characterization of chitin and chitosan from local sources. Bioresour Technol 99:1359-1367

Abdulkarim A, Isa MT, Abdulsalam S, Muhammad AJ, Ameh AO (2013) Extraction and characterisation of chitin and chitosan from Mussel Shell. Extraction 3(2):108-114

Abul A, Samad S, Huq D, Moniruzzaman M, Masum M (2015) Textile dye removal from wastewater effluents using Chitosan-Zno nanocomposite. J Textile Sci Eng 5(200):2

Agarwal S, Greiner A, Wendorff JH (2013) Functional materials by electrospinning of polymers. Prog Polym Sci 38:963-991

Ahamed MIN, Sankar S, Kashif PM, Basha SKH, Sastry TP (2015) Evaluation of biomaterial containing regenerated cellulose and chitosan incorporated with silver nanoparticles. Int J Biol Macromol 72:680-686

Ahmad M, Ahmed S, Swami BL, Ikram S (2015) Adsorption of heavy metal ions: role of chitosan and cellulose for water treatment. Langmuir 79:109-155

Aiba SI (1991) Studies on chitosan: 3. evidence for the presence of random and block copolymer structures in partially $\mathrm{N}$-acetylated chitosans. Int J Biol Macromol 13:40-44

Ameeduzzafar SS, Imam SN, Bukhari JA, Ahmad AA (2018) Formulation and optimization of levofloxacin loaded chitosan nanoparticle for ocular delivery: in-vitro characterization, ocular tolerance and antibacterial activity. Int J Biol Macromol 108:650-659

Anirudhan TS, Parvathy J (2018) Novel thiolated chitosan-polyethyleneglycol blend/montmorillonite composite formulations for the oral delivery of insulin. Bioact Carbohydr Dietary Fibre 16:22-29 
Aranaz I, Mengibar M, Harris R, Paños I, Miralles B, Acosta N, Galed G, Heras Á (2009) Functional characterization of chitin and chitosan. Curr Chem Biol 3(2):203-230

Arbia W, Arbia L, Adour L, Amrane A (2013) Chitin extraction from crustacean shells using biological methods-a review. Food Technol Biotechnol 51(1):12-25

Arun Kumar R, Sivashanmugam A, Deepthi S, Iseki S, Chennazhi KP, Nair SV, Jayakumar R (2015) Injectable Chitin-poly ( $\varepsilon$-caprolactone)/nanohydroxyapatite composite microgels prepared by simple regeneration technique for bone tissue engineering. ACS Appl Mater Interfaces 7:9399-9409

Ashry ESHE, Aly MRE (2007) Synthesis and biological relevance of N-acetylglucosamine containing oligosaccharides. Pure Appl Chem 12:2229-2242

Bano I, Arshad M, Yasin T, Ghauri MA (2019) Preparation, characterization and evaluation of glycerol plasticized chitosan/PVA blends for burn wounds. Int J Biol Macromol 124:155-162

Barikani M, Oliaei E, Seddiqi H, Honarkar H (2014) Preparation and application of chitin and its derivatives: a review. Iran Polym J 23:307-326

Benhabiles MS, Salah R, Lounici H, Drouiche N, Goosen MFA, Mameri N (2012) Antibacterial activity of chitin, chitosan and its oligomers prepared from shrimp shell waste. Food Hydrocoll 29:48-56

Berger J, Reist M, Chenite A, Felt-Baeyens O, Mayer JM, Gurny R (2005) Erratum to Pseudo-thermosetting chitosan hydrogels for biomedical application. Int J Pharm 28:197-206

Bhowmick A, Pramanik N, Manna PJ, Mitra T, Selvaraj TKR, Gnanamani A, Das M, Kundu PP (2015) Development of porous and antimicrobial CTSPEG-HAP-ZnO nano-composites for bone tissue engineering. RSC Adv 5:99385-99393

Birolli WG, Delezuk JADM, Campana-Filho SP (2016) Ultrasound-assisted conversion of alpha-chitin into chitosan. Appl Acoust 103:239-242

Bohlman JA, Schisler DO, Hwang KO, Hennling JP, Trinkle JR, Anderson TB, Steinke JD, Vanderhoff A (2004) N-Acetyl-D-glucosamine and process for producing $N$-acetyl-D-glucosamine. US Patent 6,693,188, 17 Feb 2004

Caridade SG, Monge C, Almodóvar J, Guillot R, Lavaud J, Josserand V, Coll JL, Mano JF, Picart C (2015) Myoconductive and osteoinductive freestanding polysaccharide membranes. Acta Biomater 15:139-149

Cauchie HM (2002) Chitin production by arthropods in the hydrosphere. Hydrobiologia 470:63-96

Chaput C, Chenite A (2014) Injectable in situ self-forming mineral-polymer hybrid composition and uses thereof. US Patent 8,747,899, 10 Jun 2014

Chen JK, Shen CR, Liu CL (2010) N-Acetylglucosamine: production and applications. Mar Drugs 8:2493-2516

Cheng MY, Deng JG, Yang F, Gong Y, Zhao N, Zhang X (2003) Study on physical properties and nerve cell affinity of composite films from chitosan and gelatin solutions. Biomaterials 24:2871-2880

Choorit W, Patthanamanee W, Manurakchinakorn S (2008) Use of response surface method for the determination of demineralization efficiency in fermented shrimp shells. Bioresour Technol 99:6168-6173

Community Research and Development Information Service, European Commission. http://cordis.europa.eu/home en.html. Accessed 24 Mar 2018

Dehaghi SM, Rahmanifar B, Moradi AM, Azar PA (2014) Removal of permethrin pesticide from water by chitosan-zinc oxide nanoparticles composite as an adsorbent. J Saudi Chem Soc 18(4):348-355

Demey H, Vincent T, Guibal E (2018) A novel algal-based sorbent for heavy metal removal. Chem Eng J 332:582-595

Deng H, Lin P, Li W, Xin S, Zhou X, Yang J (2013) Hydroxypropyl chitosan/ organic rectorite-based nanofibrous mats with intercalated structure for bacterial inhibition. J Biomater Sci Polym Ed 24(4):485-496

Dhillon GS, Kaur S, Brar SK, Verma M (2013) Green synthesis approach: extraction of chitosan from fungus mycelium. Crit Rev Biotechnol 33:379-403

Dhivya S, Saravanan S, Sastry TP, Selvamurugan N (2015) Nanohydroxyapatitereinforced chitosan composite hydrogel for bone tissue repair in vitro and in vivo. J Nanobiotechnol 40:1-13

D'huart JB, Dallas C (2004) Cactaceae-based formulation having the property of fixing fats, and method for obtaining same. US Patent 2004,0,126,444 A1, 1 July, 2004. https://patents.google.com/patent/US20040126444

Ding Y, Shen SZ, Sun H, Sun K, Liu F, Qi Y, Yan J (2015) Design and construction of polymerized-chitosan coated $\mathrm{Fe}_{3} \mathrm{O}_{4}$ magnetic nanoparticles and its application for hydrophobic drug delivery. Mater Sci Eng C 48:487-498
D'Mello S, Elangovan S, Hong L, Ross RD, Sumner DR, Salem AK (2015) Incorporation of copper into chitosan scaffolds promotes bone regeneration in rat calvarial defects. J Biomed Mater Res B Appl Biomater 103:1044-1049

Duan B, Gao H, He M, Zhang L (2014) Hydrophobic modification on surface of chitin sponges for highly effective separation of oil. ACS Appl Mater Interfaces 6(22): 19933-19942

Dutta PK, Dutta J, Tripathi VS (2004) Chitin and chitosan: chemistry, properties and applications. J Sci Ind Res 63:20-31. http://nopr.niscair.res.in/handl e/123456789/5397

Dutta J, Tripathi S, Dutta PK (2012) Progress in antimicrobial activities of chitin, chitosan and its oligosaccharides: a systematic study needs for food applications. Food Sci Technol Int 18:3-34

El-Diasty EM, Nesreen Z, Aideia AM (2012) Using of chitosan as antifungal agent in Kariesh Cheese. New York Sci J 5(9):5-10

Fan Y, Saito T, Isogai A (2009) TEMPO-mediated oxidation of $\beta$-chitin to prepare individual nanofibrils. Carbohydr Polym 77(4):832-838

Fan Z, Qin Y, Liu S, Xing R, Yu H, Chen X, Li K, Li P (2018) Synthesis, characterization, and antifungal evaluation of diethoxyphosphoryl polyaminoethyl chitosan derivatives. Carbohydr Polym 190:1-11

Ferreira AR, Alves VD, Coelhoso IM (2016) Polysaccharide-based membranes in food packaging applications. Membranes (Basel) 6:2

Fiamingo A, Augusto J, Delezuk DM, Trombotto S, David L, Campana-filho SP (2016) Ultrasonics sonochemistry extensively deacetylated high molecular weight chitosan from the multistep ultrasound-assisted deacetylation of beta-chitin. Ultrason Sonochem 32:79-81

Finkielsztein S, Vournakis JN (2015) Hemostatic compositions and therapeutic regimens. US 9,139,664 B2, 22 Sep, 2015. https://www.lens.org/lens/ patent/US_9139663_B2

Flores-Albino B, Arias L, Gómez J, Castillo A, Gimeno M, Shirai K (2012) Chitin and $\mathrm{L}(+)$-lactic acid production from crab (Callinectes bellicosus) wastes by fermentation of Lactobacillus sp. B2 using sugar cane molasses as carbon source. Bioprocess Biosyst Eng 35(7):1193-1200

Francis RJ, Prestwich GD, Hunt G (2015) System and method of delivering a hyaluronic acid composition and a copper composition for treatment of dermatologic conditions. WO 2015,081,304 A1, 4 June 2015. https:// patents.google.com/patent/WO2015081304A1/en

Gautier S, Xhauflaire-Uhoda E, Gonry P, Piérard GE (2008) Chitin-704 glucan, a natural cell scaffold for skin moisturization and rejuvenation. Int J Cosmet Sci 30:459-469

Ghorbel-Bellaaj O, Jellouli K, Younes I, Manni L, Ouled Salem M, Nasri M (2011) A solvent-stable metalloprotease produced by Pseudomonas aeruginosa A2 grown on shrimp shell waste and its application in chitin extraction. Appl Biochem Biotechnol 164:410-425

Ghorbel-Bellaaj O, Younes I, Maalej H, Hajji S, Nasri M (2012a) Chitin extraction from shrimp shell waste using Bacillus bacteria. Int J Biol Macromol 51:1196-1201

Ghorbel-Bellaaj O, Younes I, Maalej H, Hajji S, Nasri M (2012b) Chitin extraction from shrimp shell waste using Bacillus bacteria. Int J Biol Macromol 51(5):1196-1201

Ghosh P, Rameshbabu AP, Das D, Francis NK, Pawar HS, Subramanian B, Pal S, Dhara S (2015) Covalent cross-links in polyampholytic chitosan fibers enhances bone regeneration in a rabbit model. Colloids Surf B Biointerfaces 125:160-169

Giteru SG, Ali MA, Oey I (2019) Solvent strength and biopolymer blending effects on physicochemical properties of zein-chitosan-polyvinyl alcohol composite films. Food Hydrocolloids 86:270-286

Gooday GW (1990) The ecology of chitin degradation. Adv Microb Ecol 11:387-430

Gortari MC, Hours RA (2013) Biotechnological processes for chitin recovery out of crustacean waste: a mini-review. Electronic J Biotechnol 16(3):14. https://doi.org/10.2225/vol16-issue3-fulltext-10

Gu Y, Zhu J, Xue C, Li Z, Ding F, Yang Y, Gu X (2014) Chitosan/silk fibroin-based, Schwann cell-derived extracellular matrix-modified scaffolds for bridging rat sciatic nerve gaps. Biomaterials 357:2253-2263

Guminska M, Ignacak J, Wojcik E (1996) In vitro inhibitory effect of chitosan and its degradation products on energy metabolism in Ehrlich ascites tumour cells (EAT). Pol J Pharmacol 48:495-501

Hackbarth FV, Girardi F, Santos JC, de Souza AAU, Bonaventura RAR, de Gueli SMA, Souza U, Vilar VJP (2015) lon-exchange breakthrough curves for 
single and multi-metal systems using marine macroalgae Pelvetia canaliculata as a natural cation exchanger. Chem Eng J 269:359-370

Hai TAP, Sugimoto R (2018) Surface modification of chitin and chitosan with poly(3-hexylthiophene) via oxidative polymerization. Appl Surf Sci 434:188-197

Hajji S, Younes I, Ghorbel-Bellaaj O, Hajji R, Rinaudo M, Nasri M, Jellouli K (2014) Structural differences between chitin and chitosan extracted from three different marine sources. Int J Biol Macromol 65:298-306

Han F, Dong Y, Su Z, Yin R, Song A, Li S (2014) Preparation, characteristics and assessment of a novel gelatin-chitosan sponge scaffold as skin tissue engineering material. Int J Pharm 476:124-133

Hu FQ, Ren GF, Yuan H, Du YZ, Zeng S (2006a) Shell cross-linked stearic acid grafted chitosan oligosaccharide self-aggregated micelles for controlled release of paclitaxel. Colloids Surf B 50:97-103

Hu Z, Zhang J, Chan W, Szeto Y (2006b) The sorption of acid dye onto chitosan nanoparticles. Polymer 47(16):5838-5842

Hu FQ, Liu LN, Du YZ, Yuan H (2009) Synthesis and antitumor activity of doxorubicin conjugated stearic acid- $g$-chitosan oligosaccharide polymeric micelles. Biomaterials 30:6955-6963

Huang Y, He M, Lu A, Zhou W, Stoyanov SD, Pelan EG, Zhang L (2015) Hydrophobic modification of chitin whisker and its potential application in structuring oil. Langmuir 31(5):1641-1648

Ifuku S, Shervani Z, Saimoto H (2013) Preparation of chitin nanofibers and their composites. In: Thomas S, Pothan LA (eds) Biopolymer nanocomposites: processing, properties, and applications. Wiley, Hoboken

Iqbal P, Preece JA, Mendes PM (2012) Nanotechnology: the "Top-Down" and "Bottom-Up" approaches. In: Steed JW, Gale PA (eds) Supramolecular chemistry: from molecules to nanomaterials. Wiley, Oxford

Islam MS, Khan S, Tanaka M (2004) Waste loading in shrimp and fish processing effluents: potential source of hazards to the coastal and near shore environments. Mar Pollut Bull 49:103-110

Jeon YJ, Kim SK (2002) Antitumor activity of chitosan oligosaccharides produced in ultrafiltration membrane reactor system. J Microbiol Biotechnol 12(3):503-507

Ji J, Tong X, Huang X, Wang T, Lin Z, Cao Y, Zhang J, Dong L, Qin H, Hu Q (2015) Sphere-shaped nano-hydroxyapatite/chitosan/gelatin 3D porous scaffolds increase proliferation and osteogenic differentiation of human induced pluripotent stem cells from gingival fibroblasts. Biomed Mater 10:045005

Jiang T, Abdel-Fattah W, Laurencin CT (2006) In vitro evaluation of chitosan/ poly (lactic acid-glycolic acid) sintered microsphere scaffolds for bone tissue engineering. Biomaterials 27:4894-4903

João CFC, Silva JC, Borges JP (2015) Chitin-based nanocomposites: biomedical applications. Eco-friendly polymer nanocomposites. Springer, New Delhi, pp 439-457

Johnson EL, Nichols EJ (2000) High tap density chitosan, and methods of production. US $6130321 \mathrm{~A}$, Oct

Kadokawa JI (2015) Fabrication of nanostructured and microstructured chitin materials through gelation with suitable dispersion media. RSC Adv 5(17):12736-12746

Kaur S, Dhillon GS (2014) The versatile biopolymer chitosan: potential sources, evaluation of extraction methods and applications. Crit Rev Microbiol 40(2):155-175

Kaur S, Dhillon GS (2015) Recent trends in biological extraction of chitin from marine shell wastes: a review. Crit Rev Biotechnol 35:44-61

Keeney M, Han LH, Onyiah S, Yang F (2012) Tissue engineering: focus on the musculoskeletal system. In: Rosen Y, Elman N (eds) Biomaterial science: an integrated clinical and engineering approach. CRC-Press, New York, pp 191-221

Khanafari A, Marandi R, Sanatei S (2008) Recovery of chitin and chitosan from shrimp waste by chemical and microbial methods. Iran J Environ Health Sci Eng 5(1):19-24

Khorrami M, Najafpour GD, Younesi H, Amini GH (2011) Growth kinetics and demineralization of shrimp shell using Lactobacillus plantarum PTCC 1058 on various carbon sources. Iran J Energy Environ 2(4):320-325

Khorrami M, Najafpour GD, Younes H, Hosseinpour MN (2012) Production of chitin and chitosan from shrimp shell in batch culture of Lactobacillus plantarum. Chem Biochem Eng Quarterly 26(3):217-223. https://hrcak .srce.hr/87355

Kim YH, Gihm SH, Park CR, Lee KY, Kim TW, Kwon IC, Chung H, Jeong SY (2001) Structural characteristics of size-controlled self-aggregates of deoxycholic acid-modified chitosan and their application as a DNA delivery carrier. Bioconjugate Chem 12:932-938

Knidri HE, Khalfaouy RE, Laajeb A, Addaou A, Lahsini A (2016) Eco-friendly extraction and characterization of chitin and chitosan from the shrimp shell waste via microwave irradiation. Process Saf Environ Prot 104:395-405

Kwok KC, Koong LF, Chen G, McKay G (2014) Mechanism of arsenic removal using chitosan and nanochitosan. J Colloid Interface Sci 416:1-10

Kyzas GZ, Siafaka PI, Pavlidou EG, Chrissafis KJ, Bikiaris DN (2015) Synthesis and adsorption application of succinyl-grafted chitosan for the simultaneous removal of zinc and cationic dye from binary hazardous mixtures. Chem Eng J 259:438-448

Lai GJ, Shalumon KT, Chen JP (2015) Response of human mesenchymal stem cells to intrafibrillar nanohydroxyapatite content and extrafibrillar nanohydroxyapatite in biomimetic chitosan/silk fibroin/nanohydroxyapatite nanofibrous membrane scaffolds. Int J Nanomed 10:567-584

Lee EJ, Kim HE (2016) Accelerated bony defect healing by chitosan/silica hybrid membrane with localized bone morphogenetic protein-2 delivery. Mater Sci Eng C 59:339-345

Lee EA, Pan CH, Son JM, Kim SI (1999) Isolation and characterization of basic exochitinase from leaf extract of Rehmannia glutinosa. Biosci Biotechnol Biochem 63:1781-1783

Levengood SL, Zhang M (2014) Chitosan-based scaffolds for bone tissue engineering. J Mater Chemi B Mater Biol Med 2:3161-3184

Li F, Zhang X, Li H, Xiang L, Chen Y (2014) Preparation of self-assembled nanoparticles of chitosan oligosaccharide-graftpolycaprolactone as a carrier of bovine serum albumin drug. Biomed Mater Eng 24:2041-2048

Liu D, Chang PR, Chen M, Wu Q (2011a) Chitosan colloidal suspension composed of mechanically disassembled nanofibers. J Colloid Interface Sci 354(2):637-643

Liu D, Wu Q, Chang PR, Gao G (2011 b) Self-assembled liquid crystal film from mechanically defibrillated chitosan nanofibers. Carbohydr Polym 84(1):686-689

Lucchesi L, Xie H (2015) Wound dressing devices and methods. US 9,205,170 B2, 8 Dec 2015. https://patents.google.com/patent/US9205170

Ma J, Xin C, Tan C (2015) Preparation, physicochemical and pharmaceutical characterization of chitosan from Catharsius molossus residue. Int J Biol Macromol 80:547-556

Mahmoud NS, Ghaly AE, Arab F (2007) Unconventional approach for demineralization of deproteinized crustacean shells for chitin production. Am J Biochem Biotechnol 3:1-9

Marciello M, Rossi S, Caramella C, Remuñán-López C (2017) Freeze-dried cylinders carrying chitosan nanoparticles for vaginal peptide delivery. Carbohydr Polym 170:43-51

Masuda S, Azuma K, Kurozumi S, Kiyose M, Osaki T, Tsuka T, Itoh N, Imagawa T, Minami S, Sato K, Okamoto Y (2014) Anti-tumor properties of orally administered glucosamine and $\mathrm{N}$ acetyl-D-glucosamine oligomers in a mouse model. Carbohydr Polym 111:783-787

McCarthy S, McGrath B, Winata E (2012) Absorbable tissue dressing assemblies, systems, and methods formed from hydrophilic polymer sponge structures such as chitosan. US 8,269,058 B2, 18 Sept 2012. https://www.lens. org/lens/patent/US_8269058_B2

McCarthy SJ, Gregory KW, Wiesmann WP, Campbell TD (2014) Wound dressing and method for controlling severe, life-threatening bleeding. US 8,668,924 B2, 11 Mar 2014. https://patents.google.com/patent/US866 8924

Medovent Reaxon ${ }^{\circledR}$ http://medovent.de/en/reaxon/reaxon-nerve-guide/. Accessed 24 Mar 2018

Merzendorfer H, Zimoch L (2003) Chitin metabolism in insects: structure, function and regulation of chitin synthases and chitinases. J Exp Biol 206:4393-4412

Mincea M, Negrulescu A, Ostafe V (2012) Preparation, modification, and applications of chitin nanowhiskers: a review. Rev Adv Mater Sci 30(3):225-242

Moatarya A, Teimouria A, Bagherzadeh M, Chermahini AN, Razavizadeh R (2017) Design and fabrication of novel chitin hydrogel/chitosan/ nano diopside, composite scaffolds for tissue engineering. Ceram Int 43:1657-1668

Mohammed MH, Williams PA, Tverezovskaya O (2013) Extraction of chitin from prawn shells and conversion to low molecular mass chitosan. Food Hydrocoll 31:166-171 
Morganti P (2013) Innovation, nanotechnology and industrial sustainability by the use of natural underutilized byproducts. J Mol Biochem 2(3):137-141

Morganti P, Fabrizi G, Palombo P, Palombo M, Ruocco E, Cardillo A, Morganti G (2008) Chitin-nanofibrils: a new active cosmetic carrier. J Appl Cosmetol 26(3):113-128

Morganti P, Del Ciotto P, Carezzi F, Morganti G, Hong-Duo C (2012) From waste material a new anti-aging compound: a chitin nanofiber complex. SOFW J 138(7):30-36

Nasrin R, Biswas S, Rashid TU, Afrin S, Jahan RA, Haque P, Rahman MM (2017) Preparation of chitin-PLA laminated composite for implantable application. Bioactive Mater 2:199-207

Nishimura S, Nishi N, Tokura S, Nishimura K, Azuma I (1986) Bioactive chitin derivatives. Activation of mouse-peritoneal macrophages by $\mathrm{O}$ (carboxymethyl) chitins. Carbohydr Res 146:251-258

Olivera S, Muralidhara HB, Venkatesh K, Guna VK, Gopalakrishna K, Kumar Y (2016) Potential applications of cellulose and chitosan nanoparticles/ composites in wastewater treatment: a review. Carbohydr Polym 153:600-618

Pachapur VL, Guemiza K, Rouissi T, Sarma SJ, Brar SK (2016) Novel biological and chemical methods of chitin extraction from crustacean waste using saline water. J Chem Technol Biotechnol 91(8):2331-2339

Pal P, Pal A (2017) Surfactant-modified chitosan beads for cadmium adsorption. Int J Biol Macromol 14:1548-1555

Pangon A, Saesoo S, Saengkrit N, Ruktanonchai U, Intasanta V (2016) Hydroxyapatite-hybridized chitosan/chitin whisker bionanocomposite fibers for bone tissue engineering applications. Carbohydr Polym 144:419-427

Park BK, Kim MM (2010) Applications of chitin and its derivatives in biological medicine. Int J Mol Sci 11:5152-5164

Pearson RG, Molino Y, Williams PM, Tendler SJ, Davies MC, Roberts CJ, Shakesheff KM (2003) Spatial confinement of neurite regrowth from dorsal root ganglia within nonporous microconduits. Tissue Eng 9:201-208

Percot A, Viton C, Domard A (2003) Characterization of shrimp shell deproteinization. Biomacromol 4:1380-1385

Pfister LA, Papaloizos M, Merkle HP, Gander B (2007) Hydrogel nerve conduits produced from alginate/chitosan complexes. J Biomed Mater Res A 80:932-937

Philibert T, Lee BH, Fabien N (2017) Current status and new perspectives on chitin and chitosan as functional biopolymers. Appl Biochem Biotechnol 181:1314-1337

Pourhaghgouy M, Zamanian A, Shahrezaee M, Masouleh MP (2016) Physicochemical properties and bioactivity of freeze-cast chitosan nanocomposite scaffolds reinforced with bioactive glass. Mater Sci Eng C 58:180-186

Prameela K, Murali Mohan C, Smitha PV, Hemalatha KPJ (2010) Bioremediation of shrimp biowaste by using natural probiotic for chitin and carotenoid production an alternative method to hazardous chemical method. Int Appl Biol Pharm 1(3):903-910

Pyrzynska K (2019) Removal of cadmium from wastewaters with low-cost adsorbents. J Environ Chem Eng 7(1):102795

Qi L, Xu Z, Jiang X, Hu C, Zou X (2004) Preparation and antibacterial activity of chitosan nanoparticles. Carbohydr Res 339(16):2693-2700

Quiñones JP, Peniche H, Peniche C (2018) Chitosan based self-assembled nanoparticles in drug delivery. Polymers 10:235

Raja MA, Zeenat S, Arif M, Liu C (2016) Self-assembled nanoparticles based on amphiphilic chitosan derivative and arginine for oral curcumin delivery. Int J Nanomed 11:4397-4412

Rajendran R, Abirami M, Prabhavathi P, Premasudha P, Kanimozhi B, Manikandan A (2015) Biological treatment of drinking water by chitosan based nanocomposites. Afr J Biotechnol 14(11):930-936

Ramírez MA, Rodriquez AT, Alfonso L, Peniche C (2010) Chitin and its derivatives as biopolymers with potential agricultural applications. Biotecnol Aplicada 27(4):270-276

Rao MB, Tanksale AM, Ghatge MS, Deshpande W (1998) Molecular and biotechnological aspects of microbial proteases. Microbiol Mol Biol Rev 62:597-635

Rege PR, Block LH (1999) Chitosan processing: influence of process parameters during acidic and alkaline hydrolysis and effect of the processing sequence on the resultant chitosan's properties. Carbohydr Res $321: 235-245$
Rezakazemi M, Albadarin AB, Walker GM, Shirazian S (2018) Quantum chemical calculations and molecular modeling for methylene blue removal from water by a lignin-chitosan blend. Int J Biol Macromol 120B:2065-2075

Ribeiro JCV, Vieira RS, Melo IM, Araújo VMA, Lima V (2017) Versatility of chitosan-based biomaterials and their use as scaffolds for tissue regeneration. Sci World J 2017:8639898

Sarkar SD, Farrugia BL, Dargaville TR, Dhara S (2013) Chitosan-collagen scaffolds with nano/microfibrous architecture for skin tissue engineering. J Biomed Mater Res A 101:3482-3492

Sashiwa H, Fujishima S, Yamano N, Kawasaki N, Nakayama A, Muraki E, Aiba S (2001) Production of $N$-acetyl-D-glucosamine from $\beta$-Chitin by enzymatic hydrolysis. Chem Lett 31:308-309

Sedaghat F, Yousefzadi M, Toiserkani H, Najafipour S (2017) Bioconversion of shrimp waste Penaeus merguiensis using lactic acid fermentation: an alternative procedure for chemical extraction of chitin and chitosan. Int J Biol Macromol 104A:883-888

Sethulekshmi C (2014) Chitin and its benefits. Int J Adv Res Biol Sci 1(6):171-175

Seyedi SM, Anvaripour B, Motavassel M, Jadidi N (2013) Comparative cadmium adsorption from water by nanochitosan and chitosan. Int J Eng Innovaive Technol 2(9):145-148

Shakir M, Jolly R, Khan MS, Iram N, Khan HM (2015) Nano hydroxyapatite/chitosan starch nanocomposite as a novel bone construct: synthesis and in vitro studies. Int J Biol Macromol 80:282-292

Shalumon KT, Lai GJ, Chen CH, Chen JP (2015) Modulation of bone-specific tissue regeneration by incorporating bone morphogenetic protein and controlling the shell thickness of silk fibroin/chitosan/nanohydroxyapatite core-shell nanofibrous membranes. ACS Appl Mater Interfaces 7:21170-21181

Shariatinia Z (2019) Pharmaceutical applications of chitosan. Adv Colloid Interface Sci 263:131-194

Shekhawat A, Kahu S, Saravanan D, Jugade R (2017) Removal of Hg(II) and $\mathrm{Cd}(\mathrm{II})$ by ionic solid impregnated chitosan. Int J Biol Macromol 104:1556-1568

Sinha S, Chand S, Tripathi P (2014) Microbial degradation of chitin waste for production of chitosanase and food related bioactive compounds. Appl Biochem Microbiol 50(2):125-133

Sini TK, Santhosh S, Mathew PT (2007) Study on the production of chitin and chitosan from shrimp shell by using Bacillus subtilis fermentation. Carbohydr Res 342:2423-2429

Sivakami M, Gomathi T, Venkatesan J, Jeong H-S, Kim S-K, Sudha P (2013) Preparation and characterization of nano chitosan for treatment wastewaters. Int J Biol Macromol 57:204-212

Srinivasan H, Velayutham K, Ravichandran R (2018) Chitin and chitosan preparation from shrimp shells Penaeus monodon and its human ovarian cancer cell line, PA-1. Int J Biol Macromol 107A:662-667

Sun X, Zhu J, Gu Q, You Y (2018) Surface-modified chitin by TEMPO-mediated oxidation and adsorption of Cd(II). Colloids Surfaces A Physicochem Eng Aspects 555:103-110

Synowiecki J, Al-Khateeb NAAQ (2000) The recovery of protein hydrolysate during enzymatic isolation of chitin from shrimp Crangon crangon processing discards. Food Chem 68:147-152

Tanaka K, Yamamoto K, Kadokawa J (2014) Facile nanofibrillation of chitin derivatives by gas bubbling and ultrasonic treatments in water. Carbohydr Res 398:25-30

Tokoro A, Tatewaki N, Suzuki K, Mikami T, Suzuki S, Suzuki M (1988) Growth inhibitory effect of hexa $\mathrm{N}$-acetylchitohexaose and chitohexaose against Meth-A solid tumor. Chem Pharm Bull 36:784-790

Tokuyasu K, Mitsutomi M, Yamaguchi I, Hayashi K, Mori Y (2000) Recognition of chitooligosaccharides and their $\mathrm{N}$-acetyl groups by putative subsites of chitin deacetylase from a deuteromycete, Colletotrichum lindemuthianum. Biochemistry 39:8837-8843

Tsaih ML, Chen RH (2003) The effect of reaction time and temperature during heterogenous alkali deacetylation on degree of deacetylation and molecular weight of resulting chitosan. J Appl Polym Sci 88:2917-2923

Tu H, Yu Y, Chen J, Shi X, Zhou J, Deng H, Du Y (2017) Highly cost-effective and high-strength hydrogels as dye adsorbents from natural polymers: chitosan and cellulose. Polym Chem 8:2913-2921

Usman A, Zia KM, Zuber M, Tabasum S, Rehman S, Zia F (2016) Chitin and chitosan based polyurethanes: a review of recent advances and prospective biomedical applications. Int J Biol Macromol 86:630-645 
Viarsagh MS, Janmaleki M, Falahatpisheh HR, Masoumi J (2010) Chitosan preparation from Persian gulf shrimp shells and investigating the effect of time on the degree of deacetylation. J Paramed Sci 1:2

Wang YS, Liu LR, Jiang Q, Zhang QQ (2007) Self-aggregated nanoparticles of cholesterol-modified chitosan conjugate as a novel carrier of epirubicin. Eur Polym J 43:43-51

Wang Y, Zhang LH, Hu M, Liu HC, Wen WS, Xiao HX, Niu Y (2008) Synthesis and characterization of collagen-chitosan-hydroxyapatite artificial bone matrix. J Biomed Mater Res A 86(1):244-252

Wang XM, Zhang J, Chen H, Wang Q (2009) Preparation and characterization of collagen-based composite conduit for peripheral nerve regeneration. J Appl Polym Sci 112:3652-3662

Wang X, You C, Hu X, Zheng Y, Li Q, Feng Z, Sun H, Gao C, Han C (2013) The roles of knitted mesh-reinforced collagen-chitosan hybrid scaffold in the one-step repair of full-thickness skin defects in rats. Acta Biomater 9:7822-7832

Wang X, Wu P, Hu X, You C, Guo R, Shi H, Guo S, Zhou H, Chaoheng Y, Zhang $Y$, Han C (2016) Polyurethane membrane/knitted mesh-reinforced collagen-chitosan bilayer dermal substitute for the repair of full-thickness skin defects via a two-step procedure. J Mech Behav Biomed Mater 56:120-133

Wijesena RN, Tissera N, Kannangara YY, Lin Y, Amaratunga GAJ, Silva KMN (2015) A method for top down preparation of chitosan nanoparticles and nanofibers. Carbohydr Polym 117:731-738

Xie J, Peng C, Zhao Q, Wang X, Yuan H, Yang L, Li K, Lou X, Zhang Y (2016) Osteogenic differentiation and bone regeneration of iPSC-MSCs supported by a biomimetic nanofibrous scaffold. Acta Biomater 29:365-379

Xu Y, Bajaj M, Schneider R, Grage SL, Ulrich AS, Winter J, Gallert C (2013) Transformation of the matrix structure of shrimp shells during bacterial deproteination and demineralization. Microb Cell Fact 12:90

Yan D, Hu S, Zhou Z, Zeenat S, Cheng F, Li Y, Feng C, Cheng X, Cheng X (2018a) Different chemical groups modification on the surface of chitosan nonwoven dressing and the hemostatic properties. Int J Biol Macromol 107A:463-469

Yan JK, Qiu WY, Wang YY, Wu LX, Cheung PCK (2018b) Formation and characterization of polyelectrolyte complex synthesized by chitosan and carboxylic curdlan for 5-fluorouracil delivery. Int J Biol Macromol 107:397-405

Yang Y, Gu X, Tan R, Hu W, Wang X, Zhang P, Zhang T (2004) Fabrication and properties of a porous chitin/chitosan conduit for nerve regeneration. Biotechnol Lett 26:1793-1797

Yang YM, Wu J, Wang XD, Liu J, Ding F, Gu XS (2009) Fabrication and evaluation of chitin-based nerve guidance conduits used to promote peripheral nerve regeneration. Adv Eng Mater 11:B209-B218

Yin M, Lin X, Ren T, Li Z, Ren X, Huang TS (2018) Cytocompatible quaternized carboxymethyl chitosan/poly(vinyl alcohol) blend film loaded copper for antibacterial application. Int J Biol Macromol 120A:992-998

Yong C, Bond Y, Hui C, Talib A (2018) Extraction and physicochemical characterization of chitin and chitosan from Zophobas morio larvae in varying sodium hydroxide concentration. Int J Biol Macromol 108:135-142

Younes I, Rinaudo M (2015) Chitin and chitosan preparation from marine sources. Structure, properties and applications. Mar Drugs 13:1133-1174

Younes I, Ghorbel-Bellaaj O, Nasri R, Chaabouni M, Rinaudo M, Nasri M (2012) Chitin and chitosan preparation from shrimp shells using optimized enzymatic deproteinization. Process Biochem 47(12):2032-2039

Zhang L, Zeng Y, Cheng Z (2016) Removal of heavy metal ions using chitosan and modified chitosan: a review. J Mol Liq 214:175-191

Zhao Y, Park RD, Muzzarelli RAA (2010) Chitin deacetylases: properties and applications. Mar Drugs 8:24-46

Zhou C, Wu Q (2011) A novel polyacrylamide nanocomposite hydrogel reinforced with natural chitosan nanofibers. Colloids Surf B Biointerfaces 84(1):155-162

\section{Submit your manuscript to a SpringerOpen ${ }^{\odot}$ journal and benefit from:}

- Convenient online submission

- Rigorous peer review

- Open access: articles freely available online

- High visibility within the field

- Retaining the copyright to your article

Submit your next manuscript at $\boldsymbol{\nabla}$ springeropen.com 